\title{
Article \\ Supplementation of Ex-Situ Biofloc to Improve Growth Performance and Enhance Nutritional Values of the Pacific White Shrimp Rearing at Low Salinity Conditions
}

\author{
Umaporn Uawisetwathana ${ }^{1, *} \mathbb{D}$, Magdalena Lenny Situmorang ${ }^{2, *} \mathbb{D}$, Sopacha Arayamethakorn ${ }^{1}$, Haniswita ${ }^{2}$, \\ Gede Suantika ${ }^{2}$, Atikorn Panya ${ }^{3}{ }^{1}$, Nitsara Karoonuthaisiri ${ }^{1}$ and Wanilada Rungrassamee ${ }^{1}$ (I) \\ 1 Microarray Research Team, National Center for Genetic Engineering and Biotechnology, \\ Pathum Thani 12120, Thailand; sopacha.ara@biotec.or.th (S.A.); nitsara.kar@biotec.or.th (N.K.); \\ wanilada.run@biotec.or.th (W.R.) \\ 2 Microbial Biotechnology Research Group, School of Life Sciences and Technology, Institut Teknologi \\ Bandung, West Java 40132, Indonesia; haniswit.haniswita@ugent.be (H.); gsuantika@sith.itb.ac.id (G.S.) \\ 3 Food Biotechnology Research Team, National Center for Genetic Engineering and Biotechnology, \\ Pathum Thani 12120, Thailand; atikorn.pan@biotec.or.th \\ * Correspondence: umaporn.uaw@biotec.or.th (U.U.); situmorangml@sith.itb.ac.id (M.L.S.); \\ Tel.: +66-25646700 (ext. 3265) (U.U.); +62-2511575 (M.L.S.)
}

Citation: Uawisetwathana, U.; Situmorang, M.L.; Arayamethakorn, S.; Haniswita; Suantika, G.; Panya, A.; Karoonuthaisiri, N.; Rungrassamee, W. Supplementation of Ex-Situ Biofloc to Improve Growth Performance and Enhance Nutritional Values of the Pacific White Shrimp Rearing at Low Salinity Conditions. Appl. Sci. 2021, 11, 4598. https://doi.org/10.3390/app11104598

Academic Editor: David Ian Ellis

Received: 29 March 2021

Accepted: 14 May 2021

Published: 18 May 2021

Publisher's Note: MDPI stays neutral with regard to jurisdictional claims in published maps and institutional affiliations.

Copyright: (c) 2021 by the authors. Licensee MDPI, Basel, Switzerland. This article is an open access article distributed under the terms and conditions of the Creative Commons Attribution (CC BY) license (https:/ / creativecommons.org/licenses/by/ $4.0 /)$.
Featured Application: This ex situ biofloc technology has high potential to be a strategy for climate change adaptation and mitigation, which is useful for improving shrimp farming practice in the Asia Pacific region and for enhancing food security with high quality of shrimp to serve consumers worldwide.

Abstract: Shrimp is an important food source consumed worldwide. An intensive aquaculture system with overuse of feed in combination with detrimental effects from climate change are serious problems leading to mass mortality of cultured shrimp. Biofloc technology is an approach to managing water quality and controlling the disease to counter the negative side of intensive culture system; however, most of the biofloc applications are naturally formed, which could be inconsistent. In this study, we employed an established optimal ratio of microbial consortium called "ex-situ biofloc (BF)" to be used as a feed supplement in shrimp cultured in a zero-water discharged system at low salinity conditions. Three feeding groups (100\%commercial pellet $(\mathrm{C}), 95 \% \mathrm{C}+\mathrm{BF}, 90 \% \mathrm{C}+\mathrm{BF})$ of shrimp were cultured for six weeks. The effect of an ex-situ biofloc supplement with commercial pellet reduction showed that levels of ammonium, nitrite, nitrate and phosphate were significantly decreased in water culture. Shrimp fed with ex-situ biofloc supplement with commercial pellet reduction exhibited significantly increased shrimp weight and survival, and significantly expressed growth-related genes involving lipolysis and energy metabolism higher than those fed with 100\% commercial pellet. Nutritional analysis indicated a significant increase of docosahexaenoic acid (DHA) and eicosenoic acid (C20:1) concentrations in the ex-situ biofloc supplemented shrimp. This finding revealed the potential of ex-situ biofloc to manage water quality, improve shrimp growth performance and enhance shrimp nutritional value under intensive culture at low salinity conditions. The beneficial effects of the ex-situ biofloc in shrimp culture system make it a promising alternative strategy to mitigate climate change effects leading to the sustainable production of high-quality shrimp in the future.

Keywords: ex-situ biofloc; Pacific white shrimp; Litopenaeus vannamei; trace mineral; amino acid profile; fatty acid profile; nutritional value; feed supplement; growth performance

\section{Introduction}

Shrimp is an economically important aquatic animal due to an increasing demand from human consumption worldwide. Capturing wild shrimp presents serious problems 
of the shortage of wild shrimp and overexploitation of the ecological system. The high demand from global consumption makes shrimp aquaculture one of the fastest growing industries in the world. An intensive culture system with high stock density and overuse of feed is mostly used to increase the production yield [1,2]. However, this system has many drawbacks, especially the side effect of uneaten feed accumulation [3]. It has been estimated that $70-80 \%$ remains in the pond, in the water or the sediment [4]. The uneaten feed in the bottom of the pond is consumed by heterotrophic bacteria, including pathogenic ones such as Vibrio sp. that can naturally be found in water column. If a high level of these pathogenic bacteria is present, it can result in mass mortality of cultured shrimp [5,6]. Uneaten feed also releases ammonia to water and in higher concentrations can disturb shrimp metabolism [7]. The uneaten feed becomes an unnecessary cost that the intensive culture system has to bear [8].

In addition, FAO stated the negative impacts of climate change on aquaculture affecting the water system in shrimp ponds (temperature, $\mathrm{pH}$ and salinity) and increasing disease outbreaks (bacterial and viral pathogen infection) $[9,10]$. These are threats to global food security as they cause not only production loss but also the reduction of shrimp quality. Previously, to overcome these problems, the management of water systems to control environmental factors from climate change and the prophylactic use of antibiotics to prevent disease outbreaks were explored. However, the water management system results in high costs for the farming industry, while the use of antibiotics is not sustainable and environmentally-friendly and prohibited in many countries.

Biofloc technology presents a promising alternative to managing water systems and could potentially reduce the risk of diseases to counter the negative side of intensive closed culture systems [11]. Biofloc is an aggregate of microorganism-bacteria, microalgae and protozoa-and organic matter that has high porosity [12]. Water with high nitrogen $(\mathrm{N})$ and phosphorus $(\mathrm{P})$ compounds can pass through the pores in biofloc, allowing the nutrient exchange. Biofloc can reduce the external organic input by microbial activities and convert it into biomass, which can be used as a natural feed source for shrimp. This natural feed can decrease the use of commercial feed in the intensive culture system, thereby reducing the production cost [12].

Benefits of biofloc technology have been shown to improve water quality [13-15], increase growth in shrimp culture [16,17], protect against pathogenic Vibrio [18-20] and provide supplementary nutritional intake to many aquatic animals [12,21,22]. Generally, one of the microbial communities in biofloc, genera of Bacillus, also has the potency to help in the digestion and absorption process in the gut of shrimp by breaking down the larger particles into smaller ones and results in better growth [19]. Nonetheless, the most implemented biofloc technology is in situ biofloc which is naturally formed in the water column. The weakness of the in-situ biofloc is the unknown composition and function of the biofloc. Therefore, the production and application of ex-situ biofloc are needed in order to optimize the performance of biofloc technology with the possibility to predict and customize the function of the biofloc. The ex-situ biofloc can be produced in suspended growth bioreactors, and the dried (powdered) biofloc can be used as a feed supplement to improve growth performance, immune responses, and metabolic activities of shrimp such as Penaeus monodon [23,24] and Litopenaeus vannamei [25].

Previously, we established ex-situ biofloc containing probiotic bacteria (B. cereus, B. megaterium), microalgae (Chaetoceros calcitrans), and a consortium of nitrifying bacteria according to their beneficial effects as aforementioned. The ex-situ biofloc using an inoculum percentage $(\% v / v)$ (B. megaterium:B. cereus:C. calcitrans: Nitrifying bacteria) of 1:1:6:9 was found to be an optimal ratio based on biofloc porosity and volume (unpublished data). Despite its benefits, there is still limited knowledge on how biofloc technology affects the shrimp growth performance and enhances shrimp nutritional value for food security, especially at the molecular levels.

Therefore, in this study, we aim to evaluate the effects of the established ex-situ biofloc supplementation in Pacific white shrimp (L. vannamei) cultured on water quality 
management, the shrimp growth performance and nutritional properties, and growthrelated genes to shed light on the molecular mechanism of the benefits of the ex-situ biofloc on shrimp.

\section{Materials and Methods}

\subsection{Preparation of Ex-Situ Biofloc Production}

A consortium of B. megaterium:B. cereu:C. calcitrans: a mixture of nitrifying bacteria (Nitrosomonas sp. and Nitrobacter sp.) (1:1:6:9 $v / v)$ was prepared as an ex-situ biofloc for shrimp supplementation. Each component was inoculated to modify the medium that was made from molasses and ZA (zwitter ammonium) fertilizer at $\mathrm{C} / \mathrm{N}$ ratio of 15 with a final $\mathrm{pH}$ of $7.5 \pm 1.0$. The medium was enriched with $0.1 \% v / v \mathrm{Na}_{2} \mathrm{SiO}_{3}$ to optimize the growth of $C$. calcitrans. The components were incubated for eight days using an Imhoff cone at $27 \pm 2{ }^{\circ} \mathrm{C}$, a light intensity around $\pm 2500 \mathrm{lux}$, photoperiodism 24:0 and salinity $12 \pm 2 \mathrm{ppt}$.

\subsection{Supplementation of Ex-Situ Biofloc to Shrimp Grow-Out Culture at Low Salinity Condition}

Nine tanks containing $70 \mathrm{~L}$ of 10 ppt water were used as the experimental culture units. A group of fifteen-day old post-larval shrimp (PL15) with initial average body weight of $0.0057 \pm 0.003 \mathrm{~g}$ was distributed randomly to the experiment tanks at a density of 500 shrimps $/ \mathrm{m}^{3}$. Commercial feed (Feng Li shrimp feed, PT. Matahari Sakti, Indonesia) was provided four times daily for six weeks of the culture period. Temperature, $\mathrm{pH}$, salinity, alkalinity, dissolved oxygen and biofloc volume were maintained at the optimum range for shrimp growth [14].

Three treatment groups were tested with three replicate tanks per treatment: (1) commercial pellet treatment without biofloc supplementation $(100 \% \mathrm{C})$; (2) $5 \%(w / w)$ feed reduction supplemented with $0.3 \%(v / v)$ biofloc $(95 \% \mathrm{C}+\mathrm{BF})$; and $(3) 10 \%(w / w)$ feed reduction supplemented with $0.3 \%(v / v)$ biofloc $(90 \% \mathrm{C}+\mathrm{BF})$ (Figure 1$)$. The ex-situ biofloc was delivered every week and freshwater was regularly added to make up for water loss due to evaporation. Water quality ( $\mathrm{DO}, \mathrm{pH}$, salinity and alkalinity) was measured weekly using a portable DO meter, a $\mathrm{pH}$ meter, a refractometer and titration, respectively. Total ammonium nitrogen, $\mathrm{NO}_{2}-\mathrm{N}, \mathrm{NO}_{3}-\mathrm{N}$, and orthophosphate were measured daily following the procedures in the Standard Methods for the Examination of the Water and Wastewater [26].

Shrimp growth performance was evaluated. The final biomass was calculated as the total weight of live shrimp at the end of cultivation. Gained weight and length were measured by calculating the difference between final weight/length and initial weight/length. Specific growth rate (SGR) was calculated with this formula:

$$
\operatorname{SGR}(\% / \text { day })=\frac{\ln (\text { final weight } / \text { initial weight }) \times 100 \%}{\text { Day of cultivation }(\text { days })}
$$

At the end of the experiment, survival was measured as the percentage of live shrimp on the final day relative to the total initially stocked shrimp. Shrimp muscle was dissected, quickly frozen in liquid nitrogen and stored at $-80{ }^{\circ} \mathrm{C}$ prior to growth-related gene expression and nutritional analyses. 


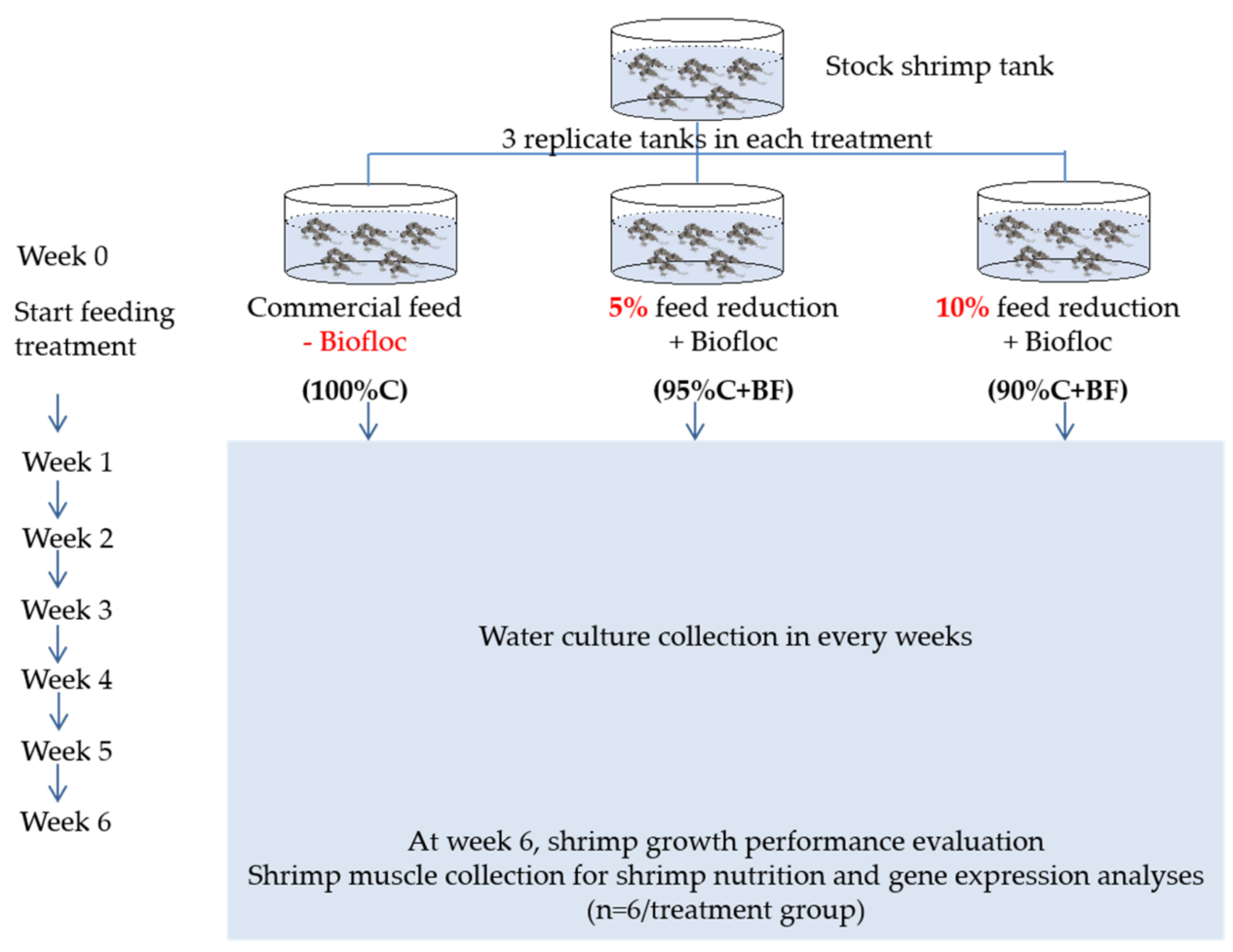

Figure 1. Experimental design in this study.

\subsection{Growth-Related Gene Expression Profiles in Shrimp Using Quantitative Realtime PCR}

Total RNA was extracted from individual shrimp muscle with TriReagent ${ }^{\circledR}$ (Molecular Research Center, Cincinnati, OH, USA) according to the manufacturer's instructions and was subsequently treated with 0.5 unit/ $\mu g$ RQ1 RNase-free DNase (Promega, Madison, WI, USA) for $30 \mathrm{~min}$ at $37^{\circ} \mathrm{C}$ to remove any contaminated genomic DNA. The concentration of total RNA was measured using a NanoDrop ND8000 spectrophotometer. Total RNA was used for cDNA synthesis with an ImProm-II ${ }^{\circledR}$ Reverse Transcriptase System kit (Promega, Madison, WI, USA) following the company's instruction.

In brief, $1.5 \mathrm{mg}$ total RNA was reverse transcribed to cDNA by priming with an oligo(dT) primer. The transcript levels of six growth-related genes containing fatty acid synthase (Fas) [27], lipase [28], carnitine palmitoyltransferase (Cpt-1) [27], cytochrome C oxidase (Cox) [29], ATP synthase (ATPase) [29], and NADH dehydrogenase (NADH) [30] were determined. Elongation factor 1 alpha (EF1a) was used as the internal control for quantitative real-time PCR (qPCR) analysis. A qPCR reaction $(20 \mu \mathrm{L})$ composing of cDNA $(0.5 \mu \mathrm{L})$, specific primers (200 $\mathrm{nM}$ each) and SsoAdvanced ${ }^{\mathrm{TM}}$ Universal SYBR ${ }^{\circledR}$ Green supermix (Bio-Rad, Irvine, CA, USA) according to the company's instruction. The thermal cycling parameters were $95^{\circ} \mathrm{C}$ for $30 \mathrm{~s}$, followed by 40 cycles of $95^{\circ} \mathrm{C}$ for $15 \mathrm{~s}, 56^{\circ} \mathrm{C}$ for $30 \mathrm{~s}$ and $72^{\circ} \mathrm{C}$ for $30 \mathrm{~s}$. The melting curve analysis was performed from $65^{\circ} \mathrm{C}$ to $95^{\circ} \mathrm{C}$ with a continuous fluorescent reading with a $0.5^{\circ} \mathrm{C}$ increment. The threshold cycle $(\mathrm{Ct})$ was analyzed using BioRad CFX Manager 2.1 software (Bio-Rad, Irvine, CA, USA). Relative mRNA abundance of each gene in the sample group was calculated based on $2^{-\Delta \Delta C t}$ method [31].

\subsection{Assessment of Nutritional Properties in Feeds and Shrimp}

The frozen ex-situ biofloc, frozen shrimp and frozen water samples were lyophilized using a lyophilizer (Christ, Harz, Germany). The freeze-dried samples were pulverized to fine powder using ball mill grinder (Retsch, Haan, Germany). The commercial pellet, which is an instant dried powder, was collected. All the fine powder samples were subject to the following nutritional analysis. 


\subsubsection{Proximate and Trace Mineral Analyses}

Proximate analyses of protein, crude fat, carbohydrate, moisture and ash were analyzed using reference AOAC methods at Central Laboratory Co., Ltd. (Song Khla, Thailand). Trace minerals containing copper, manganese, zinc, iron, calcium, magnesium, sodium and potassium were analyzed at the Environmental Research Institute, Chulalongkorn University (Bangkok, Thailand).

\subsubsection{Determination of Amino Acid Profiles in Feeds and Shrimp Using Gas} Chromatography-Mass Spectrometry (GC-MS)

Samples $(50 \mathrm{mg})$ were mixed with a hydrolysis solution $(5 \mathrm{~mL} ; 6 \mathrm{~N} \mathrm{HCl}, 5 \%$ thioglycolic acid and $0.1 \%$ phenol). The mixture was incubated at $110{ }^{\circ} \mathrm{C}$ for $18 \mathrm{~h}$ in a hot air oven (UF110, Memmert, Büchenbach, Germany). Hydrolysate sample $(1 \mathrm{~mL})$ was transferred into a new microtube and centrifuged at 10,000 $\times g$ for $10 \mathrm{~min}$ (5810R, Eppendorf, Hamburg, Germany). Then, the supernatant $(100 \mu \mathrm{L})$ was added with $1 \mathrm{M}$ sodium carbonate solution $(310 \mu \mathrm{L})$ to adjust a final $\mathrm{pH}$ to $1-2$. The mixture $(25 \mu \mathrm{L})$ was transferred into a GC vial including an internal standard $(50 \mu \mathrm{L} ; 200 \mathrm{nmol} / \mathrm{mL}$ norleucine) and dried using a speed vacuum concentrator (concentrator plus, Eppendorf) at $60^{\circ} \mathrm{C}$ for $1 \mathrm{~h}$. The dried samples were reconstituted with dichloromethane $(50 \mu \mathrm{L})$ and dried in a speed vacuum concentrator at $60{ }^{\circ} \mathrm{C}$ for $30 \mathrm{~min}$. The dried samples were derivatized using silylation reagent ( $50 \mu \mathrm{L}$; N-tert-Butyl dimethylsilyl-N-methyltrifluoroacetamide (MTBSTFA) in 1\% tert-Butyldimethyl-chlorosilane (TBDMSCl), in acetonitrile $(50 \mu \mathrm{L})$ and mixed for $30 \mathrm{~s}$. The derivatized sample was incubated in the hot air oven at $100{ }^{\circ} \mathrm{C}$ for $4 \mathrm{~h}$ prior to injection onto a GC-MS instrument (7890B, Agilent, Santa Clara, CA, USA).

The chromatographic analysis was performed on a gas chromatography (Agilent 7890B) equipped with a mass spectrometer (Agilent 7000D) and a PAL auto sampler system (CTC Analytics AG, Zwingen, Switzerland). Aliquots of the derivatized amino acids ( $2 \mu \mathrm{L})$ were injected by using pulsed split mode at 1:5 split ratio at $280^{\circ} \mathrm{C}$ into a HP-5MS column ( $30 \mathrm{~m}, 0.25 \mathrm{~mm}$ i.d., Agilent J\&W GC column). Helium was used as a carrier gas with a constant flow rate of $1.4 \mathrm{~mL} / \mathrm{min}$. The GC oven was programmed as follows: ramp from $130{ }^{\circ} \mathrm{C}$ to $190{ }^{\circ} \mathrm{C}\left(6^{\circ} \mathrm{C} / \mathrm{min}\right)$ and to $230^{\circ} \mathrm{C}\left(30^{\circ} \mathrm{C} / \mathrm{min}\right)$, held at $230^{\circ} \mathrm{C}$ for $5 \mathrm{~min}$, then ramp to $325^{\circ} \mathrm{C}$, and held at $325^{\circ} \mathrm{C}$ for $6 \mathrm{~min}$. Temperatures of transfer line, ion source (EI), and quadrupole were set at $325^{\circ} \mathrm{C}, 240^{\circ} \mathrm{C}$, and $180^{\circ} \mathrm{C}$, respectively. The mass spectrometer was acquired in selected ion monitoring (SIM) mode. The calibration curves of 20 amino acids mixtures were serially diluted in a linear range of $25-400 \mathrm{nmol} / \mathrm{mL}$. Mass spectral data of the samples were quantified by external calibration curve using Quantitative Analysis B.07.00 (Agilent Technologies, Manchester, UK).

\subsubsection{Determination of Fatty Acid Analysis in Feeds and Shrimp Using GC-MS}

Powder shrimp samples $(50 \mathrm{mg}$ ) were mixed with an ice-cold Chloroform:MeOH $(2 \mathrm{~mL} ; 1: 1 v / v)$ for $10 \mathrm{~min}$ using multi-tube vortexer (Allsheng, Hangzhou, China), sonicated for $15 \mathrm{~min}$ at $4{ }^{\circ} \mathrm{C}$ and then centrifuged at $3500 \times g$ for $20 \mathrm{~min}$ at $4{ }^{\circ} \mathrm{C}$. The supernatant was collected in a sterile glass tube and dried under a constant stream of nitrogen (TurboVap, Caliper life science, Hopkinton, MA, USA) at $35^{\circ} \mathrm{C}$ for $30 \mathrm{~min}$. The dried samples were transesterified into FAME by adding $1 \% \mathrm{H}_{2} \mathrm{SO}_{4}-\mathrm{MeOH}(1 \mathrm{~mL})$ and heating at $50{ }^{\circ} \mathrm{C}$ for $2 \mathrm{~h}$. The samples were left at room temperature to cool before being vigorously mixed with $15 \%$ $\mathrm{NaCl}(1 \mathrm{~mL})$ and hexane $(1 \mathrm{~mL})$ and centrifuged at $3500 \times g$ for $5 \mathrm{~min}$. The upper phase was collected into a $1 \mathrm{~mL}$ crimp top vial (SU860064, Supelco, Bellefonte, PA, USA) and dried under a constant stream of nitrogen for $10 \mathrm{~min}$ at $45^{\circ} \mathrm{C}$. The dried samples dissolved with hexane containing $5 \mathrm{ppm}$ of internal standard, methyl nonanoate (9:0) and injected onto a GC (7890A, Agilent Technologies, Santa Clara, CA, USA).

GC-MS analysis was performed on an Agilent 7890A GC system coupled with Agilent 5975C mass spectrometer (Agilent Technologies, Santa Clara, CA, USA). The FAME extracts $(1 \mu \mathrm{L})$ were separated on a $30 \mathrm{~m} \times 0.250 \mathrm{~mm} \times 0.25 \mu \mathrm{m}$ film thickness DB-FastFAME capillary column (G3903-63011, Agilent Technologies, Santa Clara, CA, USA) under the 
following program: an initial temperature at $50{ }^{\circ} \mathrm{C}$, ramp $35^{\circ} \mathrm{C} \min ^{-1}$ to $175{ }^{\circ} \mathrm{C}$, ramp $3^{\circ} \mathrm{C} \mathrm{min}{ }^{-1}$ to $185^{\circ} \mathrm{C}$, ramp $1.5^{\circ} \mathrm{C} \min ^{-1}$ to $190^{\circ} \mathrm{C}$ and $\operatorname{ramp} 3{ }^{\circ} \mathrm{C} \mathrm{min}{ }^{-1}$ to $230{ }^{\circ} \mathrm{C}$. Pulsed Split injection was conducted with a 15:1 split ratio, helium was used as the carrier gas and the injector temperature was $60{ }^{\circ} \mathrm{C}$. The MS detection conditions were as follows: an interface temperature, $240{ }^{\circ} \mathrm{C}$; ionization mode, EI+; electron energy, $70 \mathrm{eV}$; full/selected ion monitoring (SIM) scan acquisition mode; mass range, 55-382 amu. Samples were analyzed with the addition of the FAME standard injections to ensure the reproducibility of the chromatography. The processed chromatograms were identified by comparison of their retention time and mass spectrum using the FAME standard mixture and an online NIST mass spectral library. The peak areas of each FAME in the samples were normalized to the peak area of the internal standard (9:0) prior to analysis. The calibration curves were performed using the 37-component FAME mix with different concentrations ranging from 0.13 to $122.12 \mu \mathrm{g} / \mathrm{mL}$. Fatty acids in the samples were quantified based on the external calibration.

\subsection{Statistical Analysis}

Survival data were normalized using the arcsine transformation prior to statistical analysis. In order to evaluate the differences between all treatment groups, data on growth and survival parameters of all treatments were analyzed using one-way analysis of variance (One-way ANOVA) followed by Duncan Post-Hoc Test with 95\% confidence intervals using statistical software SPSS ${ }^{\circledR}$ Version 24.0.

Student $t$-test was used to compare nutritional properties between two different feeds (commercial pellet and ex-situ biofloc), whereas one-way analysis of variance (One-way ANOVA) followed by multiple comparison test (Tukey; $p<0.05$ ) was used to compare among shrimp samples-fed with three different treatments by SPSS ${ }^{\circledR}$ Version 15.0.

Relative fold change of gene expression among shrimp samples-fed with three different treatments was analyzed using one-way analysis of variance (One-way ANOVA) followed by Duncan Post-Hoc Test $(p<0.05)$ using SPSS ${ }^{\circledR}$ Version 15.0.

\section{Results}

3.1. Supplementation of Ex-Situ Biofloc in Shrimp Grow-Out Culture at Low Salinity Conditions 3.1.1. Water Quality Parameters

All water quality parameters, including temperature, $\mathrm{DO}, \mathrm{pH}$, salinity and alkalinity were maintained at the optimum range for shrimp growth (Table 1), while the biofloc concentration was kept at $0.3 \%(v / v)$ for $95 \% \mathrm{C}+\mathrm{BF}$ and $90 \% \mathrm{C}+\mathrm{BF}$ treatment groups.

Table 1. Water quality parameters for six weeks shrimp grow-out culture.

\begin{tabular}{ccccc}
\hline Parameter & Optimum Range & $\mathbf{1 0 0} \mathbf{C} \mathbf{C}$ & $\mathbf{9 5 \%} \mathbf{C}+\mathbf{B F}$ & $\mathbf{9 0} \mathbf{C} \mathbf{C}+\mathbf{B F}$ \\
\hline Temperature $\left({ }^{\circ} \mathrm{C}\right)$ & $28-32$ & $27.4-30.3$ & $27.8-30.8$ & $27.8-31.0$ \\
Salinity $(\mathrm{ppt})$ & $0.5-35$ & $11.0-15.7$ & $10.7-16.0$ & $11.7-16.7$ \\
$\mathrm{DO}(\mathrm{mg} / \mathrm{L})$ & $5.0-9.0$ & $5.8-6.4$ & $6.0-6.4$ & $5.9-6.5$ \\
$\mathrm{pH}$ & $7.0-8.3$ & $7.2-7.5$ & $7.3-7.5$ & $7.3-7.5$ \\
Alkalinity $(\mathrm{CaCO} / \mathrm{L})$ & $50-150$ & $50.0-70.7$ & $50.0-83.3$ & $53.3-80.0$ \\
Biofloc volume $(\mathrm{mL} / \mathrm{L})$ & $2.0-15.0$ & $0.6-0.7$ & $3.8-4.4$ & $3.4-3.8$ \\
\hline
\end{tabular}

Ammonia, nitrite, nitrate and phosphate levels in the treatments supplemented with biofloc were lower than control $(100 \% \mathrm{C})$ (Figure $2 \mathrm{a}-\mathrm{d})$. The levels of ammonia, nitrite, nitrate and phosphate in $100 \% \mathrm{C}$ were dramatically increased along the culture period while those in $95 \% \mathrm{C}+\mathrm{BF}$ and $90 \% \mathrm{C}+\mathrm{BF}$ were slightly up until week 4 and were then stable. Ammonium concentrations in biofloc-supplemented groups were significantly lower than the control group $(p<0.05)$ at week 4 (Figure $2 \mathrm{a})$. Nitrite and nitrate concentrations in biofloc-supplemented groups were significantly lower than the control group $(p<0.05)$ at week 5 (Figure 2b,c). Phosphate concentration in biofloc-supplemented groups were significantly lower than the control group $(p<0.05)$ at week 2 (Figure $2 \mathrm{~d}$ ). The results 
showed that microbial community in the ex-situ biofloc may play a role in managing and stabilizing inorganic nitrogen and phosphate molecules in the shrimp culture.

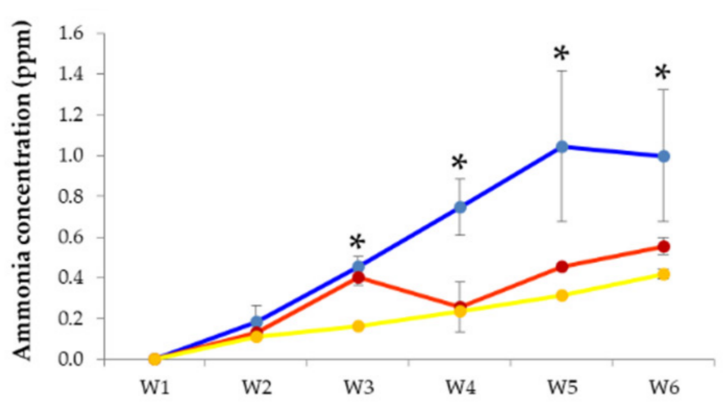

(a)

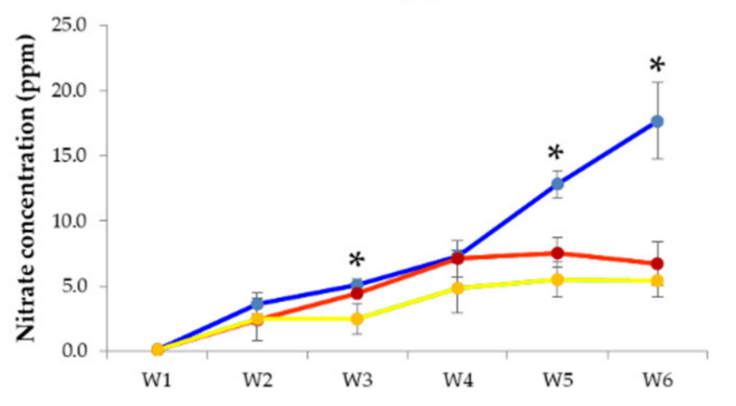

(c)

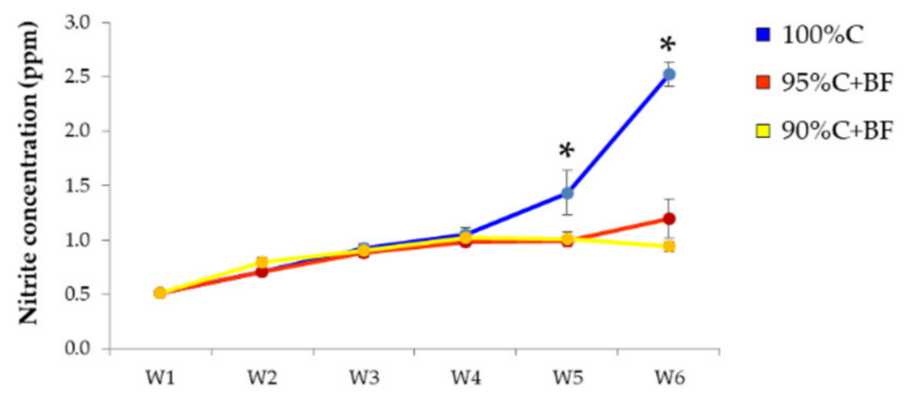

(b)

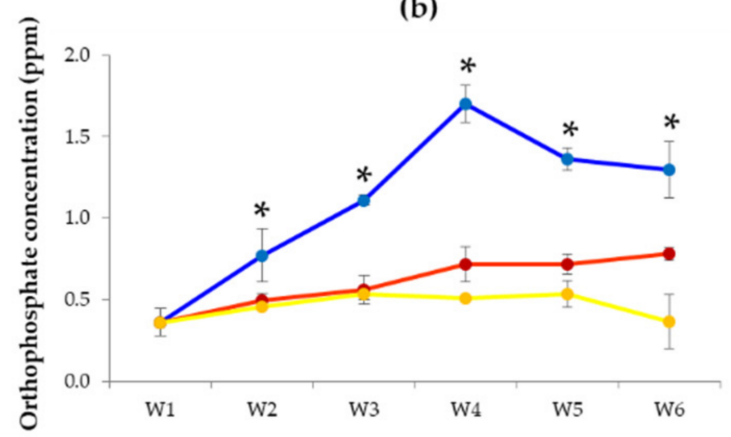

(d)

Figure 2. Concentrations of ammonia (a), nitrite (b), nitrate (c) and orthophosphate (d) concentrations during 6 weeks (W1-W6) of experiment using commercial pellet treatment without biofloc supplementation (100\%C; blue), 5\% (w/w) feed reduction supplemented with $0.3 \%(v / v)$ biofloc $(95 \% \mathrm{C}+\mathrm{BF}$; red) and $10 \%(w / w)$ feed reduction supplemented with $0.3 \%$ $(v / v)$ biofloc $(90 \% \mathrm{C}+\mathrm{BF}$; yellow). Error bars represent a value of \pm standard derivation. An asterisk represents a significant difference among the three groups at particular time point $(p<0.05)$.

\subsubsection{Shrimp Growth Performance}

At six weeks culture period, supplementation with ex-situ biofloc significantly increased the survival and growth of the shrimp (Table 2). Survival rates of shrimp-fed with commercial pellet $(100 \% \mathrm{C})$ were significantly lower than shrimp-fed with $5 \%$ and $10 \%$ pellet reduction supplemented with $0.3 \%$ ex-situ biofloc $(95 \% \mathrm{C}+\mathrm{BF}$ and $90 \% \mathrm{C}+\mathrm{BF})$. In addition, gained weight, gained length, and specific growth rate of shrimp-fed with $95 \% \mathrm{C}+\mathrm{BF}$ and $90 \% \mathrm{C}+\mathrm{BF}$ were significantly higher than those of shrimp-fed with $100 \% \mathrm{C}$. Results indicated that microbial community in the ex-situ biofloc may have a role as a feed supplement to improve shrimp growth performance.

Table 2. Shrimp growth performance with and without supplementation of ex-situ bioflocs (100\%C) and with different feeding regimes in which $95 \% \mathrm{C}+\mathrm{BF}$ were shrimp fed with $5 \%(w / w)$ feed reduction supplemented with $0.3 \%(v / v)$ biofloc, and $90 \% \mathrm{C}+\mathrm{BF}$ were shrimp fed with $10 \%(w / w)$ feed reduction supplemented with $0.3 \%(v / v)$ biofloc. Different letters above the values indicate significant differences among the treatments $(p<0.05)$.

\begin{tabular}{|c|c|c|c|}
\hline Shrimp Growth Performance & $100 \% \mathrm{C}$ & $95 \% \mathrm{C}+\mathrm{BF}$ & $90 \% \mathrm{C}+\mathrm{BF}$ \\
\hline Survival (\%) & $53.33 \pm 5.94^{\mathrm{a}}$ & $83.81 \pm 3.30^{b}$ & $85.71 \pm 7.56^{\mathrm{b}}$ \\
\hline Gained weight (g) & $0.86 \pm 0.15^{\mathrm{a}}$ & $1.97 \pm 0.14^{b}$ & $1.89 \pm 0.29 b$ \\
\hline Gained length $(\mathrm{cm})$ & $4.57 \pm 0.52^{\mathrm{a}}$ & $6.82 \pm 0.13^{b}$ & $6.92 \pm 0.22^{b}$ \\
\hline Specific Growth Rate (SGR) (\%/day) & $6.59 \pm 0.50^{\mathrm{a}}$ & $8.31 \pm 0.28^{b}$ & $8.45 \pm 0.71^{b}$ \\
\hline Biomass $\left(\mathrm{g} / \mathrm{m}^{3}\right)$ & $246.81 \pm 67.17^{\mathrm{a}}$ & $851.63 \pm 86.79^{b}$ & $826.55 \pm 44.00^{b}$ \\
\hline
\end{tabular}




\subsection{Nutritional Analysis between Commercial Pellet Diet and Ex-Situ Biofloc}

Four nutritional analyses were measured, including proximate analysis, trace mineral analysis, amino acid profile and fatty acid profile analyses. Proximate analysis showed that fat, protein and carbohydrate contents of commercial pellets were higher than those of ex-situ biofloc for 11.88, 2.93 and 2.00 folds, respectively (Table 3). On the other hand, ash and moisture contents of commercial pellet were lower than those of the ex-situ biofloc for 0.24 and 0.47 folds, respectively. The result indicated that commercial pellet had a higher major energetic nutrients than ex-situ biofloc, but the ex-situ biofloc had a larger amount of inorganic substances, which might be trace elements supplementing the energetic nutrients.

Table 3. Proximate analysis between commercial pellet and ex-situ biofloc.

\begin{tabular}{cccccc}
\hline Parameter & Unit & $\begin{array}{c}\text { Commercial } \\
\text { Pellet (C) }\end{array}$ & $\begin{array}{c}\text { Ex-Situ } \\
\text { Biofloc (BF) }\end{array}$ & $\begin{array}{c}\text { Fold Change } \\
\text { (C/BF) }\end{array}$ & $\begin{array}{c}\text { Reference } \\
\text { Method }\end{array}$ \\
\hline Ash & $\mathrm{g} / 100 \mathrm{~g}$ & 11.61 & 48.46 & 0.24 & {$[\mathrm{a}]$} \\
Carbohydrate & $\mathrm{g} / 100 \mathrm{~g}$ & 33.92 & 16.99 & 2.00 & {$[\mathrm{~b}]$} \\
Energy & Kcal/100 g & 334.84 & 126.81 & 2.64 & {$[\mathrm{~b}]$} \\
Crude fat & $\mathrm{g} / 100 \mathrm{~g}$ & 3.92 & 0.33 & 11.88 & {$[\mathrm{c}]$} \\
Moisture & $\mathrm{g} / 100 \mathrm{~g}$ & 9.58 & 20.25 & 0.47 & {$[\mathrm{~d}]$} \\
Protein & $\mathrm{g} / 100 \mathrm{~g}$ & 40.97 & 13.97 & 2.93 & {$[\mathrm{e}]$} \\
\hline [a] AOAC (2016) & 942.05. [b] Journal of AOAC International; 1993. p. 106. [c] AOAC (2016) 920.39. [d] AOAC
\end{tabular}
(2016) 930.15. [e] In-house method TE-CH-012 based on AOAC (2016) 981.10.

Trace mineral profiles analysis revealed that copper (8.49-fold increase), manganese (2.55-fold increase), and potassium (1.28-fold increase) contents in the commercial pellet were higher than those in ex-situ biofloc whereas zinc (0.27-fold decrease), iron ( 0.26 -fold decrease), calcium (0.54-fold decrease), magnesium (0.08-fold decrease) and sodium (0.03fold decrease) contents in the commercial pellet were lower than those in ex-situ biofloc (Table 4). Results indicated that a large number of essential trace minerals (zinc, iron, calcium, magnesium and sodium) for shrimp growth were observed in ex-situ biofloc.

Table 4. Trace mineral analysis between commercial pellet and ex-situ biofloc.

\begin{tabular}{cccc}
\hline Mineral (mg/kg) & $\begin{array}{c}\text { Commercial } \\
\text { Pellet (C) }\end{array}$ & Ex-Situ Biofloc (BF) & Fold Change (C/BF) \\
\hline Copper & 50.150 & 5.908 & 8.49 \\
Manganese & 30.680 & 12.020 & 2.55 \\
Zinc & 50.340 & 184.000 & 0.27 \\
Iron & 477.00 & 1857.00 & 0.26 \\
Calcium & 2064 & 3824 & 0.54 \\
Magnesium & 1928 & 25,084 & 0.08 \\
Sodium & 3898 & 129,067 & 0.03 \\
Potassium & 9956 & 7758 & 1.28 \\
\hline
\end{tabular}

In-depth analysis of amino acid and fatty acid profiles showed higher contents of 19 detected amino acids in commercial pellet than those in ex-situ biofloc in a range of 2.8-9.1 folds (Table 5). Glutamic acid, proline, glycine and arginine contents were found to be dominant in commercial pellet, whereas glutamic acid, aspartic acid, alanine, and leucine contents were found to be abundant in ex-situ biofloc. Proline and glycine found predominantly in the commercial pellet were higher than those in ex-situ biofloc for 9.08 and 5.90 folds, respectively. All essential amino acids were found to be significantly higher in the commercial pellet than those in ex-situ biofloc: threonine (4.94-fold increase), histidine (6.29-fold increase), isoleucine (3.23-fold increase), leucine (4.19-fold increase), valine (3.38-fold increase), lysine (3.50-fold increase), methionine (3.00-fold increase) and phenylalanine (3.37-fold increase). 
Table 5. Amino acid profiles between commercial pellet and ex-situ biofloc. Different letters above the values indicate significant differences between the feeds. Letters ${ }^{a}$ and ${ }^{b}$ represent statistical analysis using student- $t$-test. Different letters comparing between commercial pellet and ex-situ biofloc represent significant difference $(p<0.05)$.

\begin{tabular}{cccc}
\hline $\begin{array}{c}\text { Amino Acids } \\
(\mathbf{g} / \mathbf{1 0 0} \mathbf{g} \mathbf{D W})\end{array}$ & $\begin{array}{c}\text { Commercial } \\
\text { Pellet }(\mathbf{C})\end{array}$ & Ex Situ-Biofloc (BF) & Fold Change (C/BF) \\
\hline Alanine & $2.29 \pm 0.04^{\mathrm{a}}$ & $0.73 \pm 0.06^{\mathrm{b}}$ & 3.14 \\
Glycine & $2.95 \pm 0.09^{\mathrm{a}}$ & $0.50 \pm 0.09^{\mathrm{b}}$ & 5.90 \\
Valine & $1.76 \pm 0.06^{\mathrm{a}}$ & $0.52 \pm 0.02^{\mathrm{b}}$ & 3.38 \\
Leucine & $2.68 \pm 0.09^{\mathrm{a}}$ & $0.64 \pm 0.02^{\mathrm{b}}$ & 4.19 \\
Isoleucine & $1.55 \pm 0.06^{\mathrm{a}}$ & $0.48 \pm 0.01^{\mathrm{b}}$ & 3.23 \\
Proline & $4.63 \pm 0.12^{\mathrm{a}}$ & $0.51 \pm 0.04^{\mathrm{b}}$ & 9.08 \\
Methionine & $0.69 \pm 0.01^{\mathrm{a}}$ & $0.23 \pm 0.01^{\mathrm{b}}$ & 3.00 \\
Serine & $1.80 \pm 0.13^{\mathrm{a}}$ & $0.29 \pm 0.09^{\mathrm{b}}$ & 6.21 \\
Threonine & $1.68 \pm 0.12^{\mathrm{a}}$ & $0.34 \pm 0.08^{\mathrm{b}}$ & 4.94 \\
Phenylalanine & $1.55 \pm 0.06^{\mathrm{a}}$ & $0.46 \pm 0.02^{\mathrm{b}}$ & 3.37 \\
Aspartic acid & $2.63 \pm 0.20^{\mathrm{a}}$ & $0.77 \pm 0.27^{\mathrm{b}}$ & 3.42 \\
Hydroxyproline & $0.77 \pm 0.01^{\mathrm{a}}$ & $0.144 \pm 0.0004^{\mathrm{b}}$ & 5.35 \\
Cysteine & $0.54 \pm 0.04^{\mathrm{a}}$ & $0.053 \pm 0.003^{\mathrm{b}}$ & 10.19 \\
Glutamic acid & $5.22 \pm 0.24^{\mathrm{a}}$ & $1.44 \pm 0.39^{\mathrm{b}}$ & 3.63 \\
Lysine & $1.19 \pm 0.02^{\mathrm{a}}$ & $0.34 \pm 0.10^{\mathrm{b}}$ & 3.50 \\
Arginine & $2.89 \pm 0.06^{\mathrm{a}}$ & $0.660 \pm 0.126^{\mathrm{b}}$ & 4.38 \\
Histidine & $2.61 \pm 0.01^{\mathrm{a}}$ & $0.415 \pm 0.011^{\mathrm{b}}$ & 6.29 \\
Tyrosine & $1.27 \pm 0.05^{\mathrm{a}}$ & $0.44 \pm 0.03^{\mathrm{b}}$ & 2.89 \\
Tryptophan & $1.03 \pm 0.03^{\mathrm{a}}$ & $0.170 \pm 0.0003^{\mathrm{b}}$ & 6.06 \\
\hline
\end{tabular}

Note: Blue-colored text indicated that these calculated values were out of limit of quantification.

Unlike amino acid profiles, not all of the fatty acid content of the commercial pellet was higher than that of ex-situ biofloc (Table 6). A total of 32 fatty acids (6-24) were detected in the commercial pellet, whereas all except for erucic acid (22:1n9) and Cis13,16-docosadienoic acid (22:2) were detected in ex-situ biofloc. While both feeds share some common major fatty acids (Palmitic acid (16:0), palmitoleic acid (16:1), oleic acid $(18: 1 n 9 c)$ and eicosapentaenoic acid (20:5n3; EPA)), other major fatty acids were different. Considering amounts of fatty acid between the commercial pellet and ex-situ biofloc, 18 fatty acids showed significantly higher levels in the commercial pellet $(p<0.05)$; of these, four, namely oleic acid (18:1n9c, 11.69-fold increase), $\delta$-linolenic acid (18:3n6, 31.62-fold increase), cis-11-Eicosanoic acid (20:1, 24.22-fold increase) and DHA (22.38-fold increase) were $>10$ folds higher. On the other hands, only four fatty acids in ex-situ biofloc showed significantly higher levels than in the commercial pellet $(p<0.05)$ : myristoleic acid (14:1, 0.38 -fold decrease), palmitoleic acid (16:1, 0.51-fold decrease), cis-8,11,14-eicosatrienoic acid (20:3n6, 0.14-fold decrease) and cis-11,14,17-eicosatrienoic acid (20:3n3, 0.71-fold decrease). 
Table 6. Fatty acid profiles between commercial pellet and ex-situ biofloc. Different letters above the values indicate significant differences between the feeds. Letters ${ }^{a}$ and ${ }^{b}$ represent statistical analysis using student- $t$-test. Different letters comparing between commercial pellet and ex-situ biofloc represent significant difference $(p<0.05)$.

\begin{tabular}{|c|c|c|c|c|}
\hline Fatty Acid (mg/100 g DW) & Symbol & Commercial Pellet (C) & Ex-Situ Biofloc (BF) & Fold Change (C/BF) \\
\hline Methyl Hexanoate & $6: 0$ & $1.23 \pm 0.14^{\mathrm{a}}$ & $1.08 \pm 0.07^{\mathrm{a}}$ & 1.14 \\
\hline Methyl Octanoate & $8: 0$ & $2.03 \pm 0.01^{\mathrm{a}}$ & $2.04 \pm 0.04^{\mathrm{a}}$ & 0.99 \\
\hline Methyl Decanoate & 10:0 & ND & ND & ND \\
\hline Methyl Undecanoate & 11:0 & ND & ND & ND \\
\hline Methyl Laurate & $12: 0$ & $2.70 \pm 0.45^{\mathrm{a}}$ & $0.91 \pm 0.10^{b}$ & 2.98 \\
\hline Methyl Tridecanoate & 13:0 & ND & ND & ND \\
\hline Methyl Myristate & $14: 0$ & $36.39 \pm 7.85^{\mathrm{a}}$ & $9.44 \pm 2.43^{b}$ & 3.86 \\
\hline Myristoleic Acid Methyl Ester & $14: 1$ & $1.21 \pm 0.27^{b}$ & $3.20 \pm 0.81^{\mathrm{a}}$ & 0.38 \\
\hline Methyl Pentadecanoate & $15: 0$ & $6.55 \pm 1.42^{\mathrm{a}}$ & $2.90 \pm 0.68^{b}$ & 2.25 \\
\hline Cis-10-Pentadecanoic Acid Methyl Ester & $15: 1$ & $61.17 \pm 45.90^{\mathrm{a}}$ & $90.38 \pm 53.40^{\mathrm{a}}$ & 0.68 \\
\hline Methyl Palmitate & $16: 0$ & $215.46 \pm 30.88^{a}$ & $91.74 \pm 53.35^{b}$ & 2.35 \\
\hline Methyl Pamitoleate & $16: 1$ & $48.82 \pm 11.91^{b}$ & $95.06 \pm 25.59^{\mathrm{a}}$ & 0.51 \\
\hline Methyl Heptadecanoate & 17:0 & $16.63 \pm 4.51^{\mathrm{a}}$ & $3.76 \pm 0.92^{b}$ & 4.42 \\
\hline Cis-10-Heptadecanoic Acid Methyl Ester & $17: 1$ & $3.64 \pm 0.77^{\mathrm{a}}$ & $2.13 \pm 0.57^{b}$ & 1.71 \\
\hline Methyl Stearate & 18:0 & $79.60 \pm 25.93^{a}$ & $8.17 \pm 2.06^{b}$ & 9.75 \\
\hline Trans-9-Elaidic Methyl Ester & $18: 1 n 9 t$ & $67.15 \pm 15.97^{\mathrm{a}}$ & $5.59 \pm 1.48^{b}$ & 12.01 \\
\hline Cis-9-Oleic Acid Methyl ester & $18: 1 n 9 c$ & $158.45 \pm 16.28^{\mathrm{a}}$ & $13.55 \pm 3.52^{b}$ & 11.69 \\
\hline Linolelaidic Acid Methyl Ester & $18: 2 \mathrm{n} 6 \mathrm{t}$ & ND & ND & ND \\
\hline Methyl Linoleate & $18: 2 \mathrm{n} 6 \mathrm{c}$ & $14.05 \pm 4.95^{\mathrm{a}}$ & $4.18 \pm 3.99 b$ & 3.36 \\
\hline Gamma-Linolenic Acid Methyl Ester & $18: 3 n 6$ & $42.49 \pm 10.24^{a}$ & $1.34 \pm 0.13^{b}$ & 31.62 \\
\hline Methyl Linolenate & $18: 3 n 3$ & $42.93 \pm 10.35^{a}$ & $7.29 \pm 1.81^{b}$ & 5.89 \\
\hline Methyl Arachidate & $20: 0$ & $6.40 \pm 1.18^{\mathrm{a}}$ & $1.94 \pm 0.30^{b}$ & 3.31 \\
\hline Methyl cis-11-Eicosanoate & $20: 1$ & $18.46 \pm 3.50^{\mathrm{a}}$ & $0.76 \pm 0.06^{b}$ & 24.22 \\
\hline Cis-11,14-Eicosadienoic Acid Methyl Ester & $20: 2$ & $5.61 \pm 1.07^{\mathrm{a}}$ & $0.87 \pm 0.08^{b}$ & 6.45 \\
\hline Methyl Heneicosanoate & 21:0 & $1.36 \pm 0.12^{\mathrm{a}}$ & $0.71 \pm 0.04^{b}$ & 1.92 \\
\hline $\begin{array}{l}\text { Cis-8,11,14-Eicosatrienoic Acid Methyl } \\
\text { Ester }\end{array}$ & 20:3n6 & $3.03 \pm 0.46^{b}$ & $22.43 \pm 6.12^{a}$ & 0.14 \\
\hline $\begin{array}{l}\text { Cis-11,14,17-Eicosatrienoic Acid Methyl } \\
\text { Ester }\end{array}$ & $20: 3 n 3$ & $15.54 \pm 3.10^{a}$ & $21.77 \pm 6.02^{\mathrm{a}}$ & 0.71 \\
\hline $\begin{array}{c}\text { Methyl Cis-5,8,11,14-Eicosatetraenoic } \\
\text { Acid Methyl Ester }\end{array}$ & $20: 4 n 6$ & $2.56 \pm 0.43^{a}$ & $1.73 \pm 0.26^{b}$ & 1.48 \\
\hline $\begin{array}{c}\text { Methyl Cis-5,8,11,14,17-Eicosapentaenoic } \\
\text { Acid Methyl Ester }\end{array}$ & $20: 5 n 3$ & $43.44 \pm 9.43^{a}$ & $29.29 \pm 7.89^{a}$ & 1.48 \\
\hline Methyl Behenate & $22: 0$ & $2.44 \pm 0.35^{\mathrm{a}}$ & $1.90 \pm 0.30^{\mathrm{a}}$ & 1.28 \\
\hline Methyl Erucate & $22: \ln 9$ & $14.03 \pm 4.67$ & ND & ND \\
\hline Methyl Tricosanoate & $23: 0$ & $0.84 \pm 0.09^{a}$ & $0.75 \pm 0.11^{\mathrm{a}}$ & 1.12 \\
\hline $\begin{array}{l}\text { Cis-13,16-Docosadienoic Acid Methyl } \\
\text { Ester }\end{array}$ & $22: 2$ & $11.44 \pm 2.85$ & ND & ND \\
\hline Methyl Lignocerate & $24: 0$ & $4.45 \pm 0.78^{\mathrm{a}}$ & $2.86 \pm 0.53^{b}$ & 1.55 \\
\hline $\begin{array}{c}\text { Cis-4,7,10,13,16,19-Docosahexaenoic Acid } \\
\text { Methyl Ester }\end{array}$ & $22: 6 n 3$ & $69.92 \pm 14.57^{\mathrm{a}}$ & $3.12 \pm 0.74^{b}$ & 22.38 \\
\hline Methyl Nervonate & $24: 1$ & $3.77 \pm 1.14^{\mathrm{a}}$ & $0.94 \pm 0.37^{b}$ & 4.01 \\
\hline
\end{tabular}

Note: Blue-colored text indicated that these calculated values were out of limit of quantification. ND: not detectable.

\subsection{Nutritional Analysis in Shrimp under Different Feeding Regime}

Commercial pellets and ex-situ biofloc were fed to shrimp with a different ratio for six weeks. Nutritional contents of the shrimps (trace mineral content, amino acid profile and fatty acid profile) in each treatment group were determined to evaluate nutrients uptake into the shrimp. Trace mineral contents in shrimp-fed with $5 \%$ commercial pellet reduction and supplement with $0.3 \%$ ex-situ biofloc $(95 \% \mathrm{C}+\mathrm{BF})$ showed no significant differences to the control group $(100 \% \mathrm{C})$, whereas calcium, manganese and magnesium contents in shrimp-fed with $10 \%$ commercial pellet reduction and supplement with $0.3 \%$ ex-situ biofloc $(90 \% \mathrm{C}+\mathrm{BF})$ were significantly lower than the control group (Figure $3 \mathrm{a}, \mathrm{b})$. 


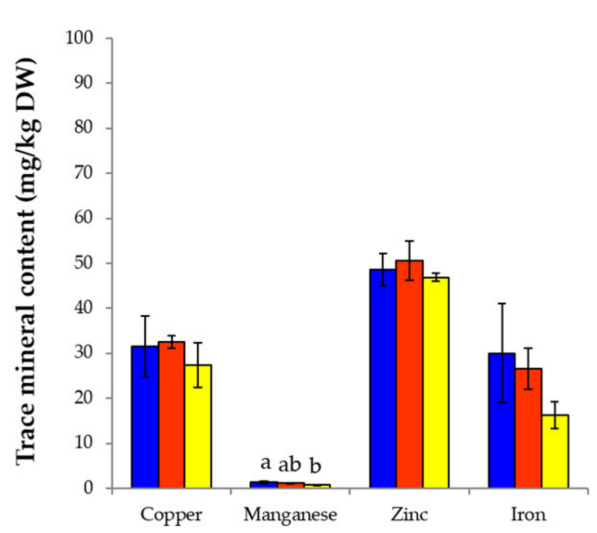

(a)

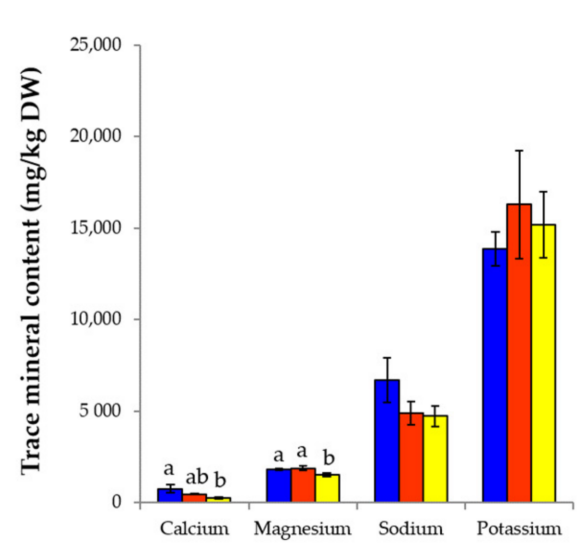

(b)

Figure 3. Trace mineral analysis of shrimp-fed with commercial pellet $(100 \% \mathrm{C}$; blue) and shrimpsupplemented with ex-situ biofloc in different commercial pellet reduction ratios $(95 \% \mathrm{C}+\mathrm{BF}$, red; 90\%C+BF, yellow). (a) Copper, Manganese, Zinc and Iron, and (b) Calcium, Magnesium, Sodium, and Potassium. Error bars represent a value of \pm standard derivation. Different letters above bars (a and $b$ ) represent a significant difference among the three groups.

For amino acid profiles, most amino acid contents in $95 \% \mathrm{C}+\mathrm{BF}-$ and $90 \% \mathrm{C}+\mathrm{BF}-\mathrm{fed}$ shrimp were not significantly different from the control shrimp $(100 \% \mathrm{C})$, except alanine, glycine and leucine, whose levels in $95 \% \mathrm{C}+\mathrm{BF}$ - fed shrimp were significantly lower than those in $100 \% \mathrm{C}$. In addition, valine, and isoleucine whose levels in both $95 \% \mathrm{C}+\mathrm{BF}$ - and $90 \% \mathrm{C}+\mathrm{BF}-$ fed shrimp were significantly lower than those in $100 \% \mathrm{C}$ (Figure 4).

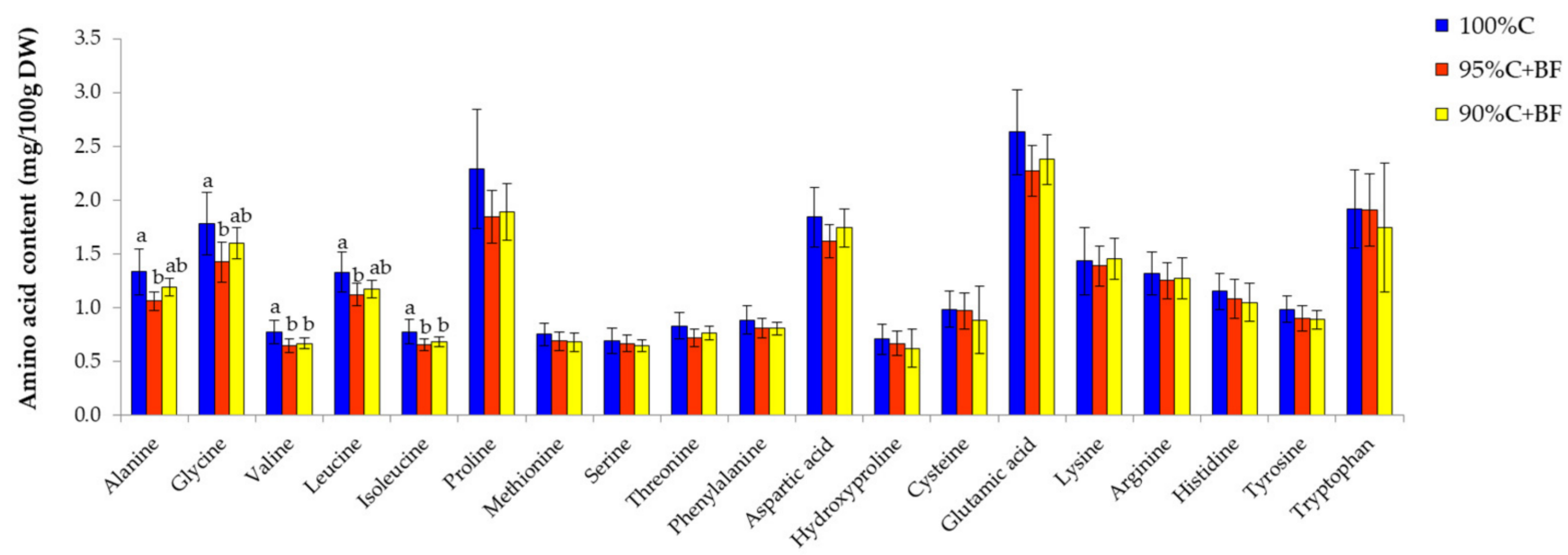

Figure 4. Amino acid profiles analysis of shrimp-fed with commercial pellet $(100 \% \mathrm{C}$, blue) and shrimp-supplemented with ex-situ biofloc in different commercial pellet reduction ratios $(95 \% \mathrm{C}+\mathrm{BF}$, red; $90 \% \mathrm{C}+\mathrm{BF}$, yellow). Error bars represent a value of \pm standard derivation. Different letters above bars ( $a$ and $b$ ) represent a significant difference among the three groups.

Fatty acid profiles in shrimp were predominant in saturated fatty acids (16:0 and 18:0), monounsaturated fatty acids $(18: 1 \mathrm{n} 9 \mathrm{c}$ and $18: 1 \mathrm{n} 9 \mathrm{t})$ and polyunsaturated fatty acids $(18: 2 \mathrm{n} 6 \mathrm{c}$, 20:3n6, 20:3n3, 20:5n3 and 22:6n3) (Figure 5a). Levels of 14:1, 16:0, 17:0 and 18:0 fatty acids in 95\%C+BF- fed shrimp were significantly higher than those in control-fed shrimp, whereas the levels of 20:1 and 22:6n3 (DHA) were significantly higher in both $95 \% \mathrm{C}+\mathrm{BF}-$ and $90 \% \mathrm{C}+\mathrm{BF}$-fed shrimp $(p<0.05)$ compared to the control group (Figure $5 \mathrm{~b})$. The rest of the detected fatty acids were not significantly different among the treatment groups. 

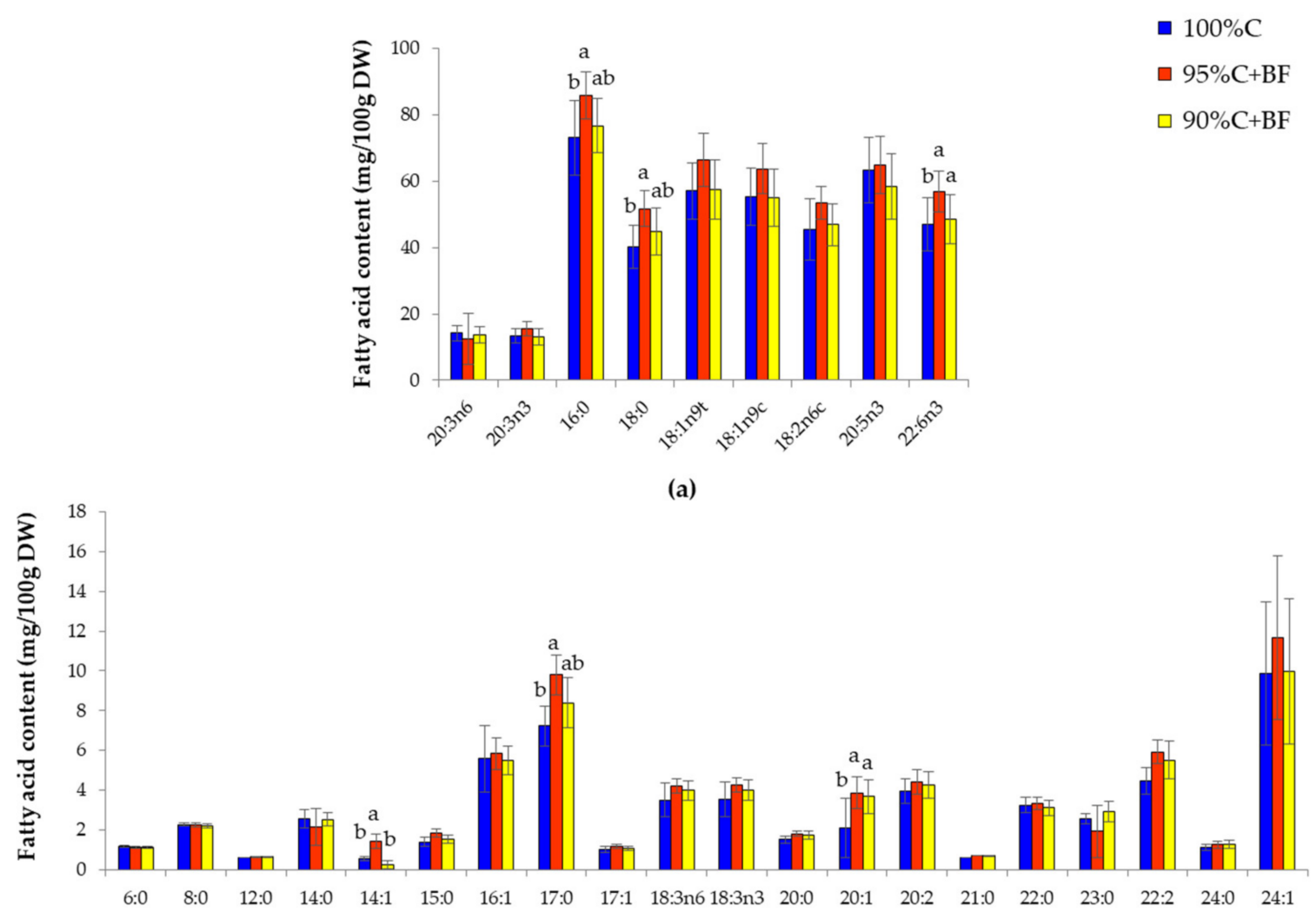

(b)

Figure 5. Fatty acid profiles analysis of shrimp-fed with commercial pellet (100\%C, blue) and shrimp-supplemented with ex-situ biofloc in different commercial pellet reduction ratios $(95 \% \mathrm{C}+\mathrm{BF}$, red; $90 \% \mathrm{C}+\mathrm{BF}$, yellow). Error bars represent a value of \pm standard derivation. Different letters above bars ( $a$ and $b$ ) represent a significant difference among the three groups.

\subsection{Gene Expression Analysis}

Six growth-related genes containing fatty acid synthase (Fas), Lipase, carnitine palmitoyltransferase (Cpt-1), cytochrome C oxidase (Cox), ATP synthase (ATPase) and NADH dehydrogenase (NADH) were examined for molecular responses in shrimp among commercial pellet feeding, and $5 \%$ and $10 \%$ commercial pellet reduction with ex-situ biofloc supplement. The expression levels of all six genes were significantly higher in both shrimp fed with $5 \%$ and $10 \%$ commercial pellet reduction with ex-situ biofloc supplement $(95 \% \mathrm{C}+\mathrm{BF}$ and $90 \% \mathrm{C}+\mathrm{BF}$, respectively) than the control $(100 \%$ C) (Figure 6).

For genes involved in lipid metabolism and the digestion process, Fas (2.15 and 3.40 folds), Lipase (2.21 and 3.13 folds), and Cpt-1 (1.79 and 1.57 folds) transcripts exhibited slightly significant increases in shrimp-fed with $95 \% \mathrm{C}+\mathrm{BF}$ and $90 \% \mathrm{C}+\mathrm{BF}$, respectively compared to the control $(100 \% \mathrm{C})$. Comparing between shrimp-fed with $95 \% \mathrm{C}+\mathrm{BF}$ and $90 \% \mathrm{C}+\mathrm{BF}$, Fas and Lipase expression levels in 90\%C+BF-fed shrimp were significantly higher than those in $95 \% \mathrm{C}+\mathrm{BF}-$ fed shrimp for 1.58 and 1.42 folds, respectively. In contrast, there was no significant difference for Cpt-1 transcript.

For genes involved in the energy metabolic process, the expression levels of ATPase (25.06 and 20.51 folds) and Cox (19.19 and 19.01 folds) were dramatically significantly higher in shrimp-fed with $95 \% \mathrm{C}+\mathrm{BF}$ and $90 \% \mathrm{C}+\mathrm{BF}$, respectively, whereas $\mathrm{NADH}$ expression level was slightly significant higher (2.91 and 2.34 folds, respectively). Comparing between shrimp-fed with $95 \% \mathrm{C}+\mathrm{BF}$ and $90 \% \mathrm{C}+\mathrm{BF}$, ATPase and $\mathrm{NADH}$ expression levels in $90 \% \mathrm{C}+\mathrm{BF}-$ fed shrimp were significantly lower than those in 95\%C+BF-fed shrimp for 1.22 and 1.01 folds, respectively, while there was no significant difference for the Cox transcript. 


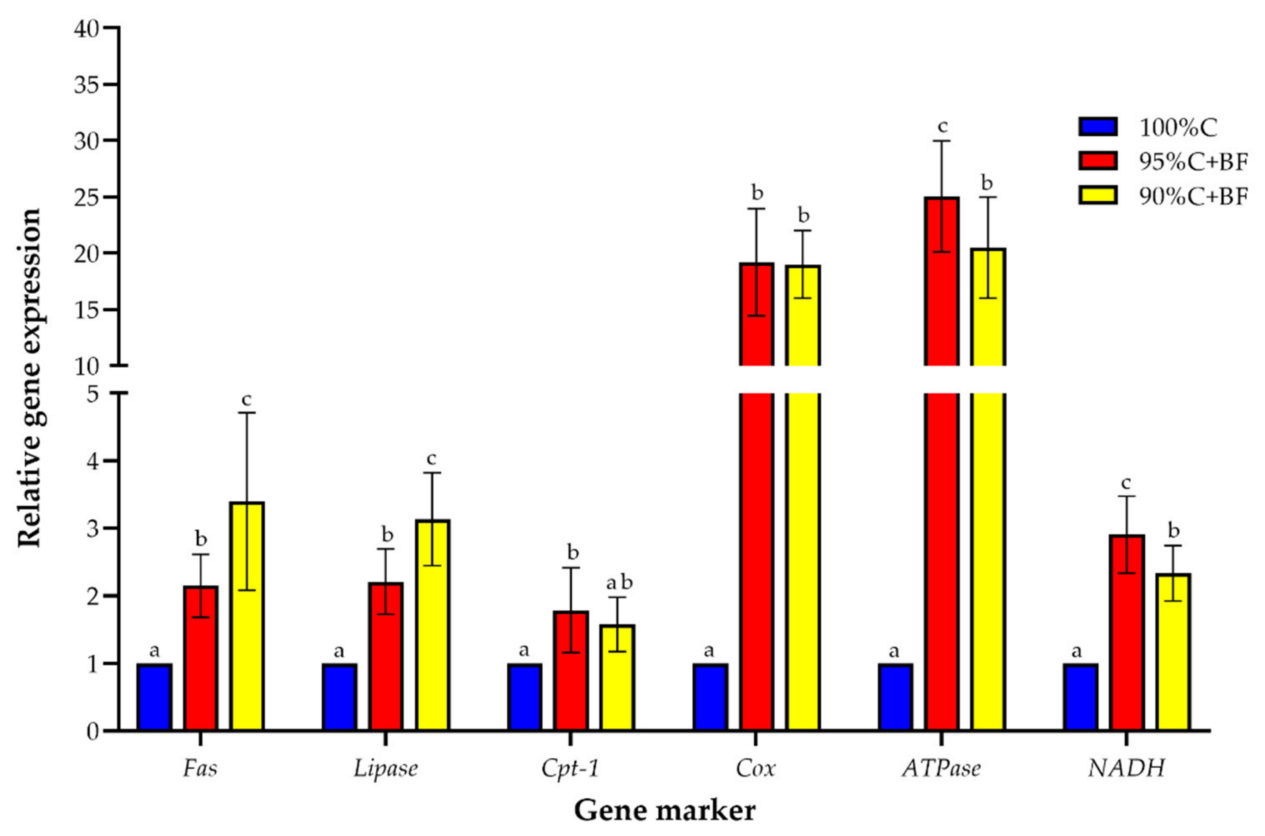

Figure 6. Relative gene expression levels (fatty acid synthase (Fas), Lipase, carnitine palmitoyltransferase (Cpt-1), cytochrome C oxidase (Cox), ATP synthase (ATPase), and NADH dehydrogenase (NADH)) in shrimp muscle from the shrimp-fed with commercial pellet $(100 \% \mathrm{C}$, blue) and shrimp-supplemented with ex-situ biofloc in different commercial pellet reduction $(95 \% \mathrm{C}+\mathrm{BF}$, red; $90 \% \mathrm{C}+\mathrm{BF}$, yellow). Error bars represent a value of \pm standard derivation. Different letters above bars $(\mathrm{a}, \mathrm{b}$ and $c)$ indicate statistical difference $(p<0.05)$ among three different groups.

\section{Discussion}

This study applied the established ex-situ biofloc containing probiotic bacteria ( $B$. cereus, B. megaterium), microalgae (Chaetoceros calcitrans), and a consortium of nitrifying bacteria as a feed supplement in Pacific white shrimp cultured upon a grow-out phase at low salinity condition. The biofloc volume used in this study is within the ranges previously suggested: 5 to $15 \mathrm{~mL} / \mathrm{L}$ (or equal to $0.5 \%$ to $1.5 \% v / v$ ) [15], $0.5,1 \%$ and $2 \%(v / v)$ [25] and 3 to $4 \mathrm{~mL} / \mathrm{L}$ (or equal to $0.3 \%$ to $0.4 \% v / v$ ) [32], which resulted in a higher specific growth rate in shrimp post-larval culture. Thus, in this study, we tested the supplementation of exsitu biofloc along with a reduction of feed amount of $5 \%$ and $10 \%$ to evaluate the potential application of ex-situ biofloc as partial replacement of artificial diets, and to evaluate the effect of ex-situ biofloc supplementation on feed utilization as well as shrimp growth performance. Considering our application, the ex-situ biofloc as a feed supplementation in the shrimp culture revealed the potential ability to maintain water quality in the ponds, improve shrimp growth performance and also enhance shrimp nutritional value. The effect of the ex-situ biofloc on the three different aspects was discussed below.

\subsection{Effect of Ex-Situ Biofloc on Water Quality Maintenance}

The ex-situ biofloc applied into the shrimp culture indicated lower ammonia, nitrite, nitrate and phosphate concentrations than the control (no ex-situ biofloc supplement). Lower ammonia concentration could be due to the activity of heterotrophic bacteria B. cereus and $B$. megaterium, a consortium of nitrifying bacteria, as well as diatom $C$. calcitrans. It has been reported that heterotrophic bacteria and diatom uptake ammonia and metabolize it into biomass [33,34], while nitrifying bacteria convert ammonia to nitrite then nitrate [15]. The nitrite and nitrate concentrations in bioflocs treatment were lower than the control, suggesting that the reduction of ammonia in the system was dominated by the activity of heterotrophic or diatom. A lower concentration of phosphate was predicted as the result of diatom activity that metabolizes orthophosphate to biomass [35]. Thus, the ex-situ biofloc 
revealed that water quality maintenance activity should be used as a good microbe starter for aquaculture.

\subsection{Effects of Ex-Situ Biofloc as Feed Supplement to Improve Shrimp Growth Performance}

Interestingly, when supplementing ex-situ biofloc with $5 \%$ and $10 \%$ commercial pellet reduction, the survival rates and the shrimp body weights were significantly higher than the control, suggesting that ex-situ biofloc might play a role as a feed supplement to enhance shrimp growth performance. From proximate analysis, commercial pellet contained a high amount of macromolecule nutrients (e.g., carbohydrate, fat and protein), while ex-situ biofloc was comprised of the high amount of minerals (e.g., zinc, iron, calcium, magnesium and sodium).

In addition, the amounts of fatty acids (stearic acid (18:0), oleic acid (18:1n9c), linoleic acid (18:2n6), linolenic acid (18:3n3), arachidonic acid (20:4n6), eicosapentaenoic acid (20:5n3; EPA) and DHA (22:6n3)) from the commercial pellet were significantly higher than those from the ex-situ biofloc. These fatty acids are essential nutrients for growth and development in animals and humans [36-38] and also play important roles in shrimp nutrition and shrimp growth and reproduction [39]. For amino acids, overall detectable amino acids (nine essential amino acids and ten non-essential amino acids) in commercial pellet were significantly higher than those in ex-situ biofloc. Proline, glutamic acid and glycine were predominant in the commercial pellet. They are involved in collagen synthesis for strengthening connective tissues such as bone, skin, cartilage and blood vessel in mammals, livestock and aquatic animals [40], maintaining digestive function and protecting the integrity of the intestinal mucosa of human [41]. This finding suggests that macromolecule nutrients from commercial pellet were the major source of nutrients feeding to shrimp; however, feed utilization efficiency may be improved by minerals obtained from ex-situ biofloc.

According to the following supported evidence, the microbial community that mainly contributes to the water quality control process was possibly from microalgae. Microalgae biomass is a well-known source of essential vitamins and minerals (e.g., $\mathrm{Na}, \mathrm{K}, \mathrm{Ca}, \mathrm{Mg}$, $\mathrm{Fe}$, and $\mathrm{Zn}$ ) [42,43]. Microalgae can also serve as "prebiotic-like" when interacting with heterotrophic bacteria in the biofloc system. This symbiosis can maintain the nutrient cycle and energy flow, resulting in balancing $\mathrm{C}$ and $\mathrm{N}$ compounds in aquaculture and supporting the aquaculture production yields [44]. Using a diatom, Chaetoceros calcitrans as feed replacement to protein, vitamins and minerals of commercial pellet in black tiger shrimp revealed increasing feed conversion efficiency, growth performance and survival [45].

Considering the roles of minerals, calcium (Ca) and magnesium (Mg) play an important role in molting and new shell formation [46]. Ca also support the growth of L. vannamei in low salinity conditions [47]. Sodium, potassium and $\mathrm{Mg}$ are essential for maintaining proper physiological function and osmoregulation in biological organisms [48]. Mg supplementation showed increasing survival of L. vannamei in low salinity conditions $[48,49]$. Zinc $(\mathrm{Zn})$ is an essential micronutrient required for plants, animals and humans for growth and reproduction [50]. Zinc also plays a pivotal role as a regulatory co-factor of different enzymes and proteins in many important biochemical pathways [51]. Zn supplementation to shrimp indicated enhancing the growth and induction of immune responses [52,53]. Iron (Fe) plays an important role in energy metabolism, homeostasis and co-factor/activator of the enzyme system $[54,55]$. It has been proven to support the growth and the survival of juvenile giant river prawns [56]. Improvement of shrimp growth performance and survival suggests that mineral contents ( $\mathrm{Zn}, \mathrm{Fe}, \mathrm{Ca}, \mathrm{Mg}$ and $\mathrm{Na}$ ) from the ex-situ biofloc were essential for biological processes such as osmoregulation, structural components of shell, co-factors of enzyme system for nutrient absorption and energy production, leading to enhanced shrimp survival and growth performance.

Most of trace mineral concentrations in shrimp flesh had no significant differences, except for calcium, magnesium and manganese, whose levels were significantly lower in the shrimp-fed with $90 \%$ commercial pellet reduction supplemented with ex-situ biofloc 
$(90 \% \mathrm{C}+\mathrm{BF})$ than those in the control group $(p<0.05)$ (Figure 3a,b). Considering trace mineral contents in feeds (Table 4), manganese concentration was higher in commercial pellets than that of ex-situ biofloc. Consequently, a lower manganese level in shrimp flesh might be correlated to the reduced level of commercial pellets. Nevertheless, our observation suggests that a lower level of manganese concentration in shrimp-fed with $90 \% \mathrm{C}+\mathrm{BF}$ was sufficient for biological processes, as there were no negative effects on shrimp survival and growth. In contrast, magnesium and calcium concentrations, which were higher in ex-situ biofloc than those of commercial pellets, were found to be significantly lower in shrimp flesh in the $90 \% \mathrm{C}+\mathrm{BF}$ group. Magnesium and calcium are a major part of shrimp exoskeletons and also play an important role for osmoregulatory purposes [46,57]. Calcium and magnesium are mostly found in the shells of Pacific white shrimp [58]. Thus, we speculated that magnesium and calcium could be mostly deposited in shells, hence lower amounts were observed in the flesh.

To elucidate the molecular mechanism, the expression levels of the selected genes related to lipid metabolism and energy metabolic process, namely fatty acid synthase (Fas), Lipase, Carnitine palmitoyltransferase-1 (Cpt-1), cytochrome Coxidase (Cox), and NADH dehydrogenase (NADH), were examined and found to be correlated to shrimp growth performance and survival. The lipid metabolism genes (Fas, Lipase and Cpt-1) were expressed higher in shrimp-fed with $5 \%$ and $10 \%$ commercial pellet reduction and ex-situ biofloc supplement, which may suggest improvement in fatty acid synthesis. The encoded gene products play a crucial role in the digestion of dietary fat [59]. Previous studies reported that Bacillus spp. could be a probiotic to stimulate digestive enzyme activity in Fenneropenaeus indicus [60], and in L. vannamei [61-63]. Cpt-1 has a primary function for energy production through the $\beta$-oxidation of fatty acids in the mitochondria in Gilthead Sea Bream fish $[64,65]$. Cox, ATPase, and NADH genes are relevant to energy metabolism. Cox plays a crucial role in the metabolic pathway associated with fatty acid $\beta$-oxidation of peroxisomal [66]. The higher expression levels of energy-related genes in the biofloc groups indicated that flux energy is increased during the feeding trail. The elevated expression levels of these transcripts suggest that the ex-situ biofloc aids in enhancing digestion of lipid, increasing feed absorption and energy production, resulting in improving feed utilization, growth performance and survival in shrimp.

\subsection{Effects of Ex-Situ Biofloc as Feed Supplement to Enhance Shrimp Nutritional}

Ex-situ biofloc supplementation in shrimp culture also affected nutritional value in shrimp as observed from amino acids and fatty acids profile in shrimp muscle. Amino acid concentrations in shrimp fed with $5 \%$ and $10 \%$ commercial pellet reduction plus ex-situ biofloc supplements were mostly found to be similar to those in the shrimp fed with only the commercial pellet, except alanine, glycine, leucine, valine and isoleucine. This result indicated that amino acid concentrations did not increase in the shrimp muscle when supplementing with ex-situ biofloc. This might be caused by the fact that excessive amounts of proteins, for example, glycine, essential for muscle development, are turned to fat molecules for storage like in humans [67] and in juvenile Pacific white shrimp [68]. Another possibility may be from gut microbial and/or probiotics absorption and utilization of amino acids into health benefit molecules to the host, resulting in amino acid homeostasis in the host cells [69]. This agreed with our observation that most of the amino acid concentrations in shrimp muscle were still similar between control and supplementing with ex-situ biofloc, containing probiotic bacteria. In addition, this finding correlated with metabolomics study of whiteleg shrimp cultured in different culturing systems (recirculating aquaculture system (RAS), hybrid zero water discharge-recirculating aquaculture system (hybrid) and outdoor earthen pond), revealing that alanine concentrations decreased in RAS and hybrid systems because super-intensive shrimp culture caused oxidative stress induction [70]. This suggests that amino acids were affected by different factors, such as stress, from super-intensive culture, microbial utilization, and nutrient storage metabolism. Therefore, 
ex-situ biofloc supplementation may not affect amino acid content in shrimp muscle in terms of nutritional value.

Interestingly, the ex-situ biofloc supplement affected fatty acid contents in shrimp muscle. Docosahexaenoic acid (DHA; 22:6n3) and eicosenoic acid (20:1) concentrations were significantly higher in shrimp fed with the ex-situ biofloc supplement with $5 \%$ and $10 \%$ commercial pellet reduction than feeding with commercial pellet alone. These fatty acids were found in both the commercial pellet and ex-situ biofloc; however, they were predominant in the commercial pellet. DHA is an omega 3 polyunsaturated fatty acid, a well-known nutrient source found in fish, shrimp, and marine organisms, that benefits visual and brain development in humans [71-74]. Eicosenoic acid (20:1) is a monounsaturated fatty acid existing in three different forms: 9-eicosenoic acid (an omega11 gadoleic acid), 11-eicosenoic acid (an omega-9 gondoic acid), and 13-eicosenoic acid (an omega-7 paullinic acid) [75]. An eicosenoic acid-rich marine oil diet showed decreasing risk factors for cardiovascular-related diseases and atherosclerosis in mice [76] and suppressing lipogenesis in mice [77]. These fatty acids were found to be beneficial to humans.

Bacillus megaterium and B. cereus contained in the ex-situ biofloc are well-known heterotropic bacteria that have been reported to be potential probiotic bacteria in other organisms. Previous studies reported that a probiotic Lactobacillus acidophilus and Lactobacillus plantarum-supplemented diet provided benefits to overall health, immunity and gut microbial composition in crayfish [78]. Brevibacillus and Fermicutes communities showed abilities to increase nutrients absorption and digestion in gut mammal [79] and in gut shrimp $p$. monodon [80]. The fact that genes related to lipid metabolism and energy metabolic process (e.g., fatty acid synthase, triacylglycerol lipase, carnitine palmitoyltransferase, NADH dehydrogenase, ATPase and cytochrome b oxidase) were expressed higher in the ex-situ biofloc shrimp also supports that ex-situ biofloc-supplement enhanced lipids digestion and absorption in shrimp muscle to boost the nutritional value. Thus, supplementation with the ex-situ biofloc influenced an increase in DHA and 20:1 concentrations in shrimp muscle, suggesting that $B$. megaterium and $B$. cereus in the ex-situ biofloc might play important roles in triggering gut microbiota to enhance nutrient absorption from the commercial pellet as well as digestion and storage of lipids, which mostly contained DHA and 20:1 fatty acids into the shrimp muscle. This mode of action not only enhanced shrimp growth performance, but also boosted the nutritional value of shrimp for human consumption.

\section{Conclusions}

This study showed that biofloc could be formed externally (ex-situ biofloc) using probiotics B. megaterium and B. cereus, diatom microalgae C. calcitrans, and consortium of nitrifying bacteria, with the ratio of 1:1:6:9 as a starter. Overall, the ex-situ biofloc supplementation in shrimp grow-out culture can increase the shrimp culture performance (shrimp growth, survival and total biomass), and provide inorganic substances such as trace minerals (calcium, manganese, zinc and iron) to support shrimp growth performance in combination with a major source of energetic nutrients (proteins and lipids) from the commercial pellet. The optimal feed formulation for the shrimp grow-out phase was the $5 \%$ reduction of the commercial pellet in supplement with $0.3 \%$ ex-situ biofloc $(95 \% \mathrm{C}+\mathrm{BF})$. Shrimp fed with $95 \% \mathrm{C}+\mathrm{BF}$ showed a significant increase of growth-related genes (e.g., fatty acid synthase, triacylglycerol lipase, carnitine palmitoyltransferase, NADH dehydrogenase, ATPase and cytochrome b oxidase) compared to the control $(100 \% \mathrm{C})$. Together, this study sheds light on the potential modes of action of ex-situ biofloc to maintain water culture quality, enhance shrimp growth performance and survival, and enable shrimp nutritional value. All these beneficial effects of ex-situ biofloc as a feed supplement in an intensive shrimp culture at low salinity conditions can be feasible for the shrimp farming industry, especially in-land culture, leading to a reduction of the cost of shrimp production and to sustaining the quality of shrimp products in the future. 
Author Contributions: Conceptualization, M.L.S. and U.U.; methodology, M.L.S. and U.U.; microbial resource and animal experiment, M.L.S., H., and G.S.; nutritional analyses, A.P. and U.U.; molecular analysis, S.A. and W.R.; data analyses, S.A., U.U. and M.L.S.; writing—original draft preparation, S.A., U.U., M.L.S.; writing-review and editing, W.R. and N.K.; visualization, S.A. and U.U.; supervision, W.R. and N.K. All authors have read and agreed to the published version of the manuscript.

Funding: This research was funded by the International Foundation for Science, Sweden, grant number J-3-B-6003-1 under the IFS collaborative grant and the publication cost was supported by BIOTEC fellow's research grant, National Center for Genetic Engineering and Biotechnology, BIOTEC, Thailand, grant number P16-52214.

Institutional Review Board Statement: Experimental protocols followed the guidelines of the Animal Care and Use Committee of Institut Teknologi Bandung, Indonesia.

Informed Consent Statement: Not applicable.

Acknowledgments: We gradually appreciate to Sorawit Powtongsook and Sage Chaiyapechara from National Center for Genetic Engineering and Biotechnology, Thailand for their valuable mentorship. We also thank to Thapakorn Somboon for his assistance in nutritional analysis.

Conflicts of Interest: The authors declare no conflict of interest.

\section{References}

1. Avnimelech, Y. Bio-filters: The need for a new comprehensive approach. Aquac. Eng. 2006, 34, 172-178. [CrossRef]

2. Burford, M.A.; Thompson, P.J.; McIntosh, R.P.; Bauman, R.H.; Pearson, D.C. The contribution of flocculated material to shrimp (Litopenaeus vannamei) nutrition in a high-intensity, zero-exchange system. Aquaculture 2004, 232, 525-537. [CrossRef]

3. Avnimelech, Y.; Ritvo, G. Shrimp and fish pond soils: Processes and management. Aquaculture 2003, 220, 549-567. [CrossRef]

4. Avnimelech, Y. Biofloc Technology: A Practical Guide Book; The World Aquaculture Society: Technion, Israel, 2009.

5. Moriarty, D.J. Disease control in shrimp aquaculture with probiotic bacteria. In Proceedings of the 8th International Symposium in Microbial Ecology, Halifax, NS, Canada, 9-14 August 1998; pp. 237-243.

6. Defoirdt, T.; Boon, N.; Sorgeloos, P.; Verstraete, W.; Bossier, P. Alternatives to antibiotics to control bacterial infections: Luminescent vibriosis in aquaculture as an example. Trends Biotechnol. 2007, 25, 472-479. [CrossRef]

7. Han, S.; Wang, B.; Liu, Q. Effects of ammonia and nitrite accumulation on the survival and growth performance of white shrimp Litopenaeus vannamei. Invertebr. Surviv. J. 2017, 14, 221-232.

8. Tacon, A.G.J.; Jory, D.E.; Nunes, A.J.P. Shrimp feed management: Issues and perspectives. In On-Farm Feeding and Feed Management in Aquaculture; Hasan, M.R., New, M.B., Eds.; FAO: Rome, Italy, 2013; pp. 481-488.

9. Thitamadee, S.; Prachumwat, A.; Srisala, J.; Jaroenlak, P.; Salachan, P.V.; Sritunyalucksana, K.; Flegel, T.W.; Itsathitphaisarn, O. Review of current disease threats for cultivated penaeid shrimp in Asia. Aquaculture 2016, 452, 69-87. [CrossRef]

10. FAO. The State of World Fisheries and Aquaculture 2016. Contributing to Food Security and Nutrition for All. Available online: www.fao.org/3/a-i5555e.pdf (accessed on 8 February 2019).

11. Crab, R.; Defoirdt, T.; Bossier, P.; Verstraete, W. Biofloc technology in aquaculture: Beneficial effects and future challenges. Aquaculture 2012, 356-357, 351-356. [CrossRef]

12. De Schryver, P.; Crab, R.; Defoirdt, T.; Boon, N.; Verstraete, W. The basics of bio-flocs technology: The added value for aquaculture. Aquaculture 2008, 277, 125-137. [CrossRef]

13. Xu, W.; Xu, Y.; Su, H.; Hu, X.; Yang, K.; Wen, G.; Cao, Y. Characteristics of ammonia removal and nitrifying microbial communities in a hybrid biofloc-RAS for intensive Litopenaeus vannamei culture: A pilot-scale study. Water 2020, 12, 3000. [CrossRef]

14. Suantika, G.; Situmorang, M.L.; Kurniawan, J.B.; Pratiwi, S.A.; Aditiawati, P.; Astuti, D.I.; Azizah, F.F.N.; Djohan, Y.A.; Zuhri, U.; Simatupang, T.M. Development of a zero water discharge (ZWD)-Recirculating aquaculture system (RAS) hybrid system for super intensive white shrimp (Litopenaeus vannamei) culture under low salinity conditions and its industrial trial in commercial shrimp urban farming in Gresik, East Java, Indonesia. Aquac. Eng. 2018, 82, 12-24. [CrossRef]

15. Emerenciano, M.G.C.; Martínez- Córdova, L.R.; Martínez-Porchas, M.; Miranda-Baeza, A. Biofloc Technology (BFT): A tool for water quality management in aquaculture, water quality. IntechOpen 2017. [CrossRef]

16. Arantes, R.; Schveitzer, R.; Magnotti, C.; Lapa, K.R.; Vinatea, L. A comparison between water exchange and settling tank as a method for suspended solids management in intensive biofloc technology systems: Effects on shrimp (Litopenaeus vannamei) performance, water quality and water use. Aquac. Res. 2017, 48, 1478-1490. [CrossRef]

17. Brito, L.O.; Arana, L.A.V.; Soares, R.B.; Severi, W.; Miranda, R.H.; da Silva, S.M.B.C.; Coimbra, M.R.M.; Gálvez, A.O. Water quality, phytoplankton composition and growth of Litopenaeus vannamei (Boone) in an integrated biofloc system with Gracilariabirdiae (Greville) and Gracilaria domingensis (Kützing). Aquac. Int. 2014, 22, 1649-1664. [CrossRef]

18. Seraspe, E.B.; Ticar, B.F.; Formacion, M.J.; Pahila, I.G.; de la Peña, M.R.; Amar, E.C. Antibacterial properties of the microalgae Chaetoceros calcitrans. Asian Fish. Sci. 2012, 25, 343-356. 
19. Vidal, J.M.A.; Pessoa, M.N.D.C.; Santos, F.L.D.; Mendes, P.P.; Mendes, M.S. Probiotic potential of Bacillus cereus against Vibrio spp. in post-larvae shrimps. Rev. Caatinga 2018, 31, 495-503. [CrossRef]

20. Kumar, V.; Wille, M.; Lourenço, T.M.; Bossier, P. Biofloc-Based enhanced survival of Litopenaeus vannamei upon AHPND-causing Vibrio parahaemolyticus challenge is partially mediated by reduced expression of its virulence genes. Front. Microbiol. $2020,11$. [CrossRef]

21. Martínez-Córdova, L.R.; Emerenciano, M.; Miranda-Baeza, A.; Martínez-Porchas, M. Microbial-based systems for aquaculture of fish and shrimp: An updated review. Rev. Aquac. 2015, 7, 131-148. [CrossRef]

22. Jiménez-Ordaz, F.J.; Cadena-Roa, M.A.; Pacheco-Vega, J.M.; Rojas-Contreras, M.; Tovar-Ramírez, D.; Arce-Amezquita, P.M. Microalgae and probiotic bacteria as biofloc inducers in a hyper-intensive Pacific white shrimp (Penaeus vannamei) culture. Lat. Am. J. Aquat. Res. 2021, 49. [CrossRef]

23. Anand, P.S.S.; Kohli, M.P.S.; Kumar, S.; Sundaray, J.K.; Roy, S.D.; Venkateshwarlu, G.; Sinha, A.; Pailan, G.H. Effect of dietary supplementation of biofloc on growth performance and digestive enzyme activities in Penaeus monodon. Aquaculture 2014, 418-419, 108-115. [CrossRef]

24. Shyne Anand, P.S.; Kumar, S.; Kohli, M.P.S.; Sundaray, J.K.; Sinha, A.; Pailan, G.H.; Dam Roy, S. Dietary biofloc supplementation in black tiger shrimp, Penaeus monodon: Effects on immunity, antioxidant and metabolic enzyme activities. Aquac. Res. 2017, 48, 4512-4523. [CrossRef]

25. Lee, C.; Kim, S.; Lim, S.-J.; Lee, K.-J. Supplemental effects of biofloc powder on growth performance, innate immunity, and disease resistance of Pacific white shrimp Litopenaeus vannamei. Fish. Aquat. Sci. 2017, 20, 15. [CrossRef]

26. APHA. Standard Method for the Examination of the Water and Wastewater, 22nd ed.; Public Health Association: Washington, DC, USA, 1998.

27. Xie, S.; Liu, Y.; Tian, L.; Niu, J.; Tan, B. Low dietary fish meal induced endoplasmic reticulum stress and impaired phospholipids metabolism in juvenile pacific white shrimp, Litopenaeus vannamei. Front. Physiol. 2020, 11, 1024. [CrossRef] [PubMed]

28. Wei, J.; Zhang, X.; Yu, Y.; Li, F.; Xiang, J. RNA-Seq reveals the dynamic and diverse features of digestive enzymes during early development of Pacific white shrimp Litopenaeus vannamei. Comp. Biochem. Physiol. Part D Genom. Proteom. 2014, 11, 37-44. [CrossRef] [PubMed]

29. Lage, L.P.A.; Plagnes-Juan, E.; Putrino, S.M.; Baron, F.; Weissman, D.; Guyonvarch, A.; Brugger, R.; Nunes, A.J.P.; Panserat, S. Ontogenesis of metabolic gene expression in whiteleg shrimp (Litopenaeus vannamei): New molecular tools for programming in the future. Aquaculture 2017, 479, 142-149. [CrossRef]

30. Ning, P.; Zheng, Z.; Aweya, J.J.; Yao, D.; Li, S.; Ma, H.; Wang, F.; Zhang, Y. Litopenaeus vannamei notch affects lipopolysaccharides induced reactive oxygen species. Dev. Comp. Immunol. 2018, 81, 74-82. [CrossRef]

31. Livak, K.J.; Schmittgen, T.D. Analysis of relative gene expression data using real-time quantitative PCR and the 2(-Delta Delta C(T)) Method. Methods 2001, 25, 402-408. [CrossRef]

32. Hai, T.N.; Tao, T.T.; Khoa, T.N.D.; Khanh, L.V.; Anh, N.T.N. Nursery of the black tiger shrimp Penaeus monodon postlarvae in a biofloc system with different carbon sources. Oceanogr. Fish Open Access J 2020, 11, 555821. [CrossRef]

33. Kirchman, D.L. The uptake of inorganic nutrients by heterotrophic bacteria. Microb. Ecol. 1994, 28, 255-271. [CrossRef]

34. Amin, S.A.; Parker, M.S.; Armbrust, E.V. Interactions between diatoms and bacteria. Microbiol. Mol. Biol. Rev. 2012, 76, 667-684. [CrossRef]

35. Delgadillo-Mirquez, L.; Lopes, F.; Taidi, B.; Pareau, D. Nitrogen and phosphate removal from wastewater with a mixed microalgae and bacteria culture. Biotechnol. Rep. 2016, 11, 18-26. [CrossRef]

36. Tocher, D.R.; Betancor, M.B.; Sprague, M.; Olsen, R.E.; Napier, J.A. Omega-3 long-chain polyunsaturated fatty acids, EPA and DHA: Bridging the gap between supply and demand. Nutrients 2019, 11, 89. [CrossRef]

37. Shurson, G.C.; Kerr, B.J.; Hanson, A.R. Evaluating the quality of feed fats and oils and their effects on pig growth performance. J. Anim. Sci. Biotechnol. 2015, 6, 10. [CrossRef]

38. Innis, S.M. Palmitic Acid in Early Human Development. Crit. Rev. Food Sci. Nutr. 2016, 56, 1952-1959. [CrossRef]

39. Glencross, B.D. Exploring the nutritional demand for essential fatty acids by aquaculture species. Rev. Aquac. 2009, 1, 71-124. [CrossRef]

40. Li, P.; Wu, G. Roles of dietary glycine, proline, and hydroxyproline in collagen synthesis and animal growth. Amino Acids 2018, 50, 29-38. [CrossRef]

41. Li, X.; Rezaei, R.; Li, P.; Wu, G. Composition of amino acids in feed ingredients for animal diets. Amino Acids 2011, 40, 1159-1168. [CrossRef]

42. Becker, W. Microalgae in Human and Animal Nutrition; Richmond, A., Ed.; Blackwell Science: Hoboken, NJ, USA, 2004.

43. Fox, J.M.; Zimba, P.V. Chapter 8-Minerals and trace elements in microalgae. In Microalgae in Health and Disease Prevention; Levine, I.A., Fleurence, J., Eds.; Academic Press: Cambridge, MA, USA, 2018; pp. 177-193. [CrossRef]

44. Natrah, F.M.I.; Bossier, P.; Sorgeloos, P.; Yusoff, F.M.; Defoirdt, T. Significance of microalgal-bacterial interactions for aquaculture. Rev. Aquac. 2014, 6, 48-61. [CrossRef]

45. Naorbe, M.C.; Garibay, S.; Serrano, A. Simultaneous replacement of protein, vitamins and minerals with Chaetoceros calcitrans paste in the diet of the black tiger shrimp (Penaeus monodon) larvae. ABAH Bioflux 2015, 7, $28-36$.

46. ICAR—Central Institute of Brackishwater Aquaculture. Applications of Mineral in Shrimp Culture Systems; CIBA: Chennai, India, 2016. 
47. Cheng, K.-M.; Hu, C.-Q.; Liu, Y.-N.; Zheng, S.-X.; Qi, X.-J. Effects of dietary calcium, phosphorus and calcium/phosphorus ratio on the growth and tissue mineralization of Litopenaeus vannamei reared in low-salinity water. Aquaculture 2006, 251, 472-483. [CrossRef]

48. Davis, D.A.; Boyd, C.E.; Rouse, D.B.; Saoud, I.P. Effects of Potassium, Magnesium and age on growth and survival of Litopenaeus vannamei post-larvae reared in inland low salinity well waters in west alabama. J. World Aquac. Soc. 2005, 36, 416-419. [CrossRef]

49. Roy, L.A.; Davis, D.A.; Saoud, I.P.; Henry, R.P. Effects of varying levels of aqueous potassium and magnesium on survival, growth, and respiration of the Pacific white shrimp, Litopenaeus vannamei, reared in low salinity waters. Aquaculture 2007, 262, 461-469. [CrossRef]

50. Frassinetti, S.; Bronzetti, G.; Caltavuturo, L.; Cini, M.; Croce, C.D. The role of zinc in life: A review. J. Environ. Pathol. Toxicol. Oncol. 2006, 25, 597-610. [CrossRef] [PubMed]

51. Maret, W. Zinc biochemistry: From a single zinc enzyme to a key element of life. Adv. Nutr. 2013, 4, 82-91. [CrossRef] [PubMed]

52. Shi, B.; Xu, F.; Zhou, Q.; Regan, M.K.; Betancor, M.B.; Tocher, D.R.; Sun, M.; Meng, F.; Jiao, L.; Jin, M. Dietary organic zinc promotes growth, immune response and antioxidant capacity by modulating zinc signaling in juvenile Pacific white shrimp (Litopenaeus vannamei). Aquac. Rep. 2021, 19, 100638. [CrossRef]

53. Lin, S.; Lin, X.; Yang, Y.; Li, F.; Luo, L. Comparison of chelated zinc and zinc sulfate as zinc sources for growth and immune response of shrimp (Litopenaeus vannamei). Aquaculture, 2003; 406-407, 79-84. [CrossRef]

54. Galbraith, E.D.; Le Mézo, P.; Solanes Hernandez, G.; Bianchi, D.; Kroodsma, D. Growth limitation of marine fish by low iron availability in the open ocean. Front. Mar. Sci. 2019, 6. [CrossRef]

55. Boyd, C.E. Health \& Welfare: The Importance of Iron in Aquaculture Systems. Glob. Aquac. 2016. Available online: https: //www.aquaculturealliance.org/advocate/the-importance-of-iron-in-aquaculture-systems/ (accessed on 4 March 2020).

56. Adhikari, S.; Naqvi, A.A.; Pani, K.C.; Pillai, B.R.; Jena, J.K.; Sarangi, N. Effect of manganese and iron on growth and feeding of juvenile giant river prawn, Macrobrachium rosenbergii (De-Man). J. World Aquac. Soc. 2007, 38, 161-168. [CrossRef]

57. Huner, J.V.; Kowalczuk, J.G.; Avault, J.W., Jr. Calcium and magnesium levels in the intermolt (C4) carapaces of the three species of freshwater crawfish (Cambaridae: Decapoda). Comp. Biochem. Physiol. Part A Physiol. 1976, 55, 183-185. [CrossRef]

58. Galkanda-Arachchige, H.S.C.; Roy, L.A.; Davis, D.A. The effects of magnesium concentration in low-salinity water on growth of Pacific white shrimp (Litopenaeus vannamei). Aquac. Res. 2021, 52, 589-597. [CrossRef]

59. Pirahanchi, Y.; Sharma, S. Lipase; StatPearls Publishing: Treasure Island, FL, USA, 2020.

60. Ziaei-Nejad, S.; Rezaei, M.H.; Takami, G.A.; Lovett, D.L.; Mirvaghefi, A.-R.; Shakouri, M. The effect of Bacillus spp. bacteria used as probiotics on digestive enzyme activity, survival and growth in the Indian white shrimp Fenneropenaeus indicus. Aquaculture 2006, 252, 516-524. [CrossRef]

61. Zokaeifar, H.; Balcázar, J.L.; Saad, C.R.; Kamarudin, M.S.; Sijam, K.; Arshad, A.; Nejat, N. Effects of Bacillus subtilis on the growth performance, digestive enzymes, immune gene expression and disease resistance of white shrimp, Litopenaeus vannamei. Fish Shellfish Immunol. 2012, 33, 683-689. [CrossRef] [PubMed]

62. Bernal, M.G.; Marrero, R.M.; Campa-Córdova, Á.I.; Mazón-Suástegui, J.M. Probiotic effect of Streptomyces strains alone or in combination with Bacillus and Lactobacillus in juveniles of the white shrimp Litopenaeus vannamei. Aquac. Int. 2017, 25, 927-939. [CrossRef]

63. Miandare, H.K.; Mirghaed, A.T.; Hosseini, M.; Mazloumi, N.; Zargar, A.; Nazari, S. Dietary Immunogen ${ }^{\circledR}$ modulated digestive enzyme activity and immune gene expression in Litopenaeus vannamei post larvae. Fish Shellfish Immunol. 2017, 70, 621-627. [CrossRef] [PubMed]

64. Sargent, J.R.; Tocher, D.R.; Bell, J.G. Fish Nutrition; Halver, J.E., Hardey, R.W., Eds.; Academic Press: Cambridge, MA, USA, 2002.

65. Turkmen, S.; Perera, E.; Zamorano, M.J.; Simó-Mirabet, P.; Xu, H.; Pérez-Sánchez, J.; Izquierdo, M. Effects of dietary lipid composition and fatty acid desaturase 2 expression in broodstock gilthead sea bream on lipid metabolism-related genes and methylation of the fads2 gene promoter in their offspring. Int. J. Mol. Sci. 2019, 20, 6250. [CrossRef]

66. Wanders, R.J. Peroxisomes, lipid metabolism, and peroxisomal disorders. Mol. Genet. Metab. 2004, 83, 16-27. [CrossRef]

67. Caldow, M.K.; Ham, D.J.; Trieu, J.; Chung, J.D.; Lynch, G.S.; Koopman, R. Glycine protects muscle cells from wasting in vitro via mTORC1 signaling. Front. Nutr. 2019, 6. [CrossRef]

68. Xie, S.-W.; Tian, L.-X.; Jin, Y.; Yang, H.-J.; Liang, G.-Y.; Liu, Y.-J. Effect of glycine supplementation on growth performance, body composition and salinity stress of juvenile Pacific white shrimp, Litopenaeus vannamei fed low fishmeal diet. Aquaculture 2014, 418-419, 159-164. [CrossRef]

69. Jäger, R.; Zaragoza, J.; Purpura, M.; Iametti, S.; Marengo, M.; Tinsley, G.M.; Anzalone, A.J.; Oliver, J.M.; Fiore, W.; Biffi, A.; et al. Probiotic administration increases amino acid absorption from plant protein: A placebo-controlled, randomized, double-blind, multicenter, crossover study. Probiotics Antimicrob. Proteins 2020, 12, 1330-1339. [CrossRef]

70. Suantika, G.; Situmorang, M.L.; Saputra, F.I.; Putri, S.L.E.; Putri, S.P.; Aditiawati, P.; Fukusaki, E. Metabolite profiling of whiteleg shrimp Litopenaeus vannamei from super-intensive culture in closed aquaculture systems: A recirculating aquaculture system and a hybrid zero water discharge-recirculating aquaculture system. Metabolomics 2020, 16, 49. [CrossRef]

71. Jónasdóttir, S.H. Fatty acid profiles and production in marine phytoplankton. Mar. Drugs 2019, 17, 151. [CrossRef]

72. Ahmmed, M.K.; Ahmmed, F.; Tian, H.; Carne, A.; Bekhit, A.E.-D. Marine omega-3 (n-3) phospholipids: A comprehensive review of their properties, sources, bioavailability, and relation to brain health. Compr. Rev. Food Sci. Food Saf. 2020, 19, 64-123. [CrossRef] 
73. Durmus, M. Fish oil for human health: Omega-3 fatty acid profiles of marine seafood species. Food Sci. Technol. $2019,39,454-461$. [CrossRef]

74. Saini, R.K.; Song, M.-H.; Rengasamy, K.R.R.; Ko, E.-Y.; Keum, Y.-S. Red shrimp are a rich source of nutritionally vital lipophilic compounds: A comparative study among edible flesh and processing waste. Foods 2020, 9, 1179. [CrossRef]

75. Pereira, H.; Barreira, L.; Figueiredo, F.; Custódio, L.; Vizetto-Duarte, C.; Polo, C.; Rešek, E.; Engelen, A.; Varela, J. Polyunsaturated Fatty acids of marine macroalgae: Potential for nutritional and pharmaceutical applications. Mar. Drugs 2012, 10, 1920-1935. [CrossRef]

76. Yang, Z.-H.; Emma-Okon, B.; Remaley, A.T. Dietary marine-derived long-chain monounsaturated fatty acids and cardiovascular disease risk: A mini review. Lipids Health Dis. 2016, 15, 201. [CrossRef]

77. Senarath, S.; Yoshinaga, K.; Nagai, T.; Yoshida, A.; Beppu, F.; Gotoh, N. Differential effect of cis-eicosenoic acid positional isomers on adipogenesis and lipid accumulation in 3T3-L1 cells. Eur. J. Lipid Sci. Technol. 2018, 120, 1700512. [CrossRef]

78. Foysal, M.J.; Fotedar, R.; Siddik, M.A.B.; Tay, A. Lactobacillus acidophilus and L. plantarum improve health status, modulate gut microbiota and innate immune response of marron (Cherax cainii). Sci. Rep. 2020, 10, 5916. [CrossRef]

79. Ley, R.E.; Hamady, M.; Lozupone, C.; Turnbaugh, P.J.; Ramey, R.R.; Bircher, J.S.; Schlegel, M.L.; Tucker, T.A.; Schrenzel, M.D.; Knight, R.; et al. Evolution of mammals and their gut microbes. Science 2008, 320, 1647-1651. [CrossRef]

80. Uengwetwanit, T.; Uawisetwathana, U.; Arayamethakorn, S.; Khudet, J.; Chaiyapechara, S.; Karoonuthaisiri, N.; Rungrassamee, W. Multi-omics analysis to examine microbiota, host gene expression and metabolites in the intestine of black tiger shrimp (Penaeus monodon) with different growth performance. PeerJ 2020, 8, e9646. [CrossRef] 